\title{
Article \\ Oxidative Stress Conditions Result in Trapping of PHF-Core Tau (297-391) Intermediates
}

\author{
Mahmoud B. Maina 1,2 ${ }^{\mathbb{D}}$, Youssra K. Al-Hilaly 1,3 ${ }^{\mathbb{D}}$, Gunasekhar Burra 1,4 ${ }^{\mathbb{D}}$, Janet E. Rickard ${ }^{5}$, \\ Charles R. Harrington ${ }^{5,6}{ }^{(D)}$, Claude M. Wischik ${ }^{5,6}$ and Louise C. Serpell ${ }^{1, *}$
}

1 Sussex Neuroscience, School of Life Sciences, University of Sussex, Brighton BN1 9QG, UK; m.bukar-maina@sussex.ac.uk (M.B.M.); ya45@sussex.ac.uk (Y.K.A.-H.); gunasekhar.iitk@gmail.com (G.B.)

2 College of Medical Sciences, Yobe State University, Damaturu P.M.B. 1144, Nigeria

3 Chemistry Department, College of Sciences, Mustansiriyah University, Baghdad, Iraq

4 Analytical Research and Development, Pharma Division, Biological E. Limited, Genome Valley, IKP-Shameerpet, Hyderabad 500 078, Telangana, India

5 Institute of Medical Sciences, University of Aberdeen, Aberdeen AB25 2ZP, UK; j.rickard@abdn.ac.uk (J.E.R.); c.harrington@abdn.ac.uk (C.R.H.); cmw@taurx.com (C.M.W.)

6 TauRx Therapeutics Ltd., Aberdeen AB24 5RP, UK

* Correspondence: L.C.Serpell@sussex.ac.uk

check for updates

Citation: Maina, M.B.; Al-Hilaly, Y.K.; Burra, G.; Rickard, J.E.;

Harrington, C.R.; Wischik, C.M.;

Serpell, L.C. Oxidative Stress

Conditions Result in Trapping of

PHF-Core Tau (297-391)

Intermediates. Cells 2021, 10, 703.

https://doi.org/10.3390/cells10

030703

Academic Editor: Carla Perego

Received: 19 February 2021

Accepted: 15 March 2021

Published: 22 March 2021

Publisher's Note: MDPI stays neutral with regard to jurisdictional claims in published maps and institutional affiliations.

Copyright: (c) 2021 by the authors. Licensee MDPI, Basel, Switzerland. This article is an open access article distributed under the terms and conditions of the Creative Commons Attribution (CC BY) license (https:/ / creativecommons.org/licenses/by/ $4.0 /)$.
Abstract: The self-assembly of tau into paired helical filaments (PHFs) in neurofibrillary tangles (NFTs) is a significant event in Alzheimer's disease (AD) pathogenesis. Numerous post-translational modifications enhance or inhibit tau assembly into NFTs. Oxidative stress, which accompanies AD, induces multiple post-translational modifications in proteins, including the formation of dityrosine (DiY) cross-links. Previous studies have revealed that metal-catalysed oxidation (MCO) using $\mathrm{Cu}^{2+}$ and $\mathrm{H}_{2} \mathrm{O}_{2}$ leads to the formation of DiY cross-links in two misfolding proteins, $\mathrm{A} \beta$ and $\alpha$-synuclein, associated with AD and Parkinson's disease respectively. The effect of MCO on tau remains unknown. Here, we examined the effect of MCO and ultra-violet oxidation to study the influence of DiY crosslinking on the self-assembly of the PHF-core tau fragment. We report that DiY cross-linking facilitates tau assembly into tau oligomers that fail to bind thioflavin $S$, lack $\beta$-sheet structure and prevents their elongation into filaments. At a higher concentration, $\mathrm{Cu}^{2+}$ (without $\mathrm{H}_{2} \mathrm{O}_{2}$ ) also facilitates the formation of these tau oligomers. The DiY cross-linked tau oligomers do not cause cell death. Our findings suggest that DiY cross-linking of pre-assembled tau promotes the formation of soluble tau oligomers that show no acute impact on cell viability.

Keywords: Alzheimer's disease; tau; dityrosine; paired helical filaments; oxidative stress

\section{Introduction}

Alzheimer's disease (AD) is the most common form of dementia, characterised by the deposition of extracellular amyloid-beta $(A \beta)$ plaques and accumulation of intracellular neurofibrillary tangles (NFTs). NFTs are comprised of paired helical filaments (PHFs) and straight filaments (SFs) composed of tau [1,2]. The burden of NFTs is correlated with the extent of pathology in AD [3], and NFT accumulation provides a reliable staging of the disease process [4]. The formation of filaments involves the self-assembly of tau monomers to oligomers, but the precise mechanisms involved are not fully understood. Some types of oligomers are likely to convert to PHFs and SFs [5]. The different forms of abnormal tau aggregates have been linked with specific dysfunctions associated with memory deficits: cellular toxicity [5], synaptic dysfunction, mitochondrial disturbance, and the spread of tau pathology across the brain in mouse models [6-9]. Tau oligomers have also been identified in the early stages of $\mathrm{AD}[10]$.

The self-assembly of tau is influenced by a myriad of post-translational modifications [11]. For example, while tau phosphorylation and truncation are thought to contribute to the assembly of tau filaments [11], nitration of tyrosine residues has been shown 
to inhibit the assembly of arachidonic acid-induced tau filaments [12]. Multiple studies have shown that oxidative stress generates tau post-translational modifications including phosphorylation $[13,14]$, acetylation $[15,16]$, nitration, nitrotyrosine and dityrosine (DiY) formation [12]. Oxidative stress is one of the earliest sources of damage identified in $\mathrm{AD}$ [17] and key markers of oxidative stress, such as nitrotyrosine and DiY levels, are increased in the AD brain [18]. DiY cross-linking results in a stable, irreversible modification of proteins [19]. A $\beta$ and $\alpha$-synuclein (associated with Parkinson's disease) have both been shown to form DiY cross-links in vitro [20-23]. The modification of tyrosine residues by oxidative stress has been previously demonstrated to influence tau aggregation [12,24]. For example, it has been shown that oxidative stress induced by peroxynitrite, results in the oligomerisation of full-length human tau induced by arachidonic acid, and these are stabilised via DiY cross-linking [12]. Although this indicates that DiY forms in tau, it is not clear whether DiY formation promotes tau self-assembly into filaments or stabilises tau oligomers in vivo. Tau is usually induced to form filaments in vitro with the help of heparin arachidonic acid or other polyanionic molecules [25-29]. A truncated tau fragment, however, known as dGAE, was recently shown to self-assemble into filaments in vitro without the addition of exogenous additives [30,31]. This tau fragment, corresponding to residues Ile297-Glu391, was first isolated from the proteolytically stable core of PHFs [2] and more recently has been found to overlap with the region identified in the PHF and SF core solved by cryo-electron microscopy [32].

The longest isoform of tau with 441 amino acid residues contains five tyrosine residues, located at positions 18,29,197,310, and 394. The dGAE fragment contains a region thought to be important for assembly competence ${ }^{306} \mathrm{VQIVYK}^{311}$ [33,34], which contains Y310. Therefore, the dGAE fragment serves as an ideal in vitro model to investigate the influence of oxidative conditions on $\mathrm{DiY}$ formation within tau and to characterise its propensity to assemble in the absence of exogeneous additives. Using metal-catalysed oxidation (MCO) and ultra-violet (UV)-induced photo-oxidation to induce DiY cross-linking, we show that the oxidation of soluble dGAE facilitates assembly into Thioflavin S (ThS)-negative tau oligomers that lack $\beta$-sheet structure and which do not elongate into fibrils. Moreover, our results reveal that, at a higher (10:1) $\mathrm{Cu}^{2+}$ : dGAE ratio, $\mathrm{Cu}^{2+}$ alone (without $\mathrm{H}_{2} \mathrm{O}_{2}$ ) facilitates the formation of these DiY cross-linked tau oligomers, prolongs the oligomer half-life and inhibits further assembly into fibrils. We report that, unlike other tau oligomers previously reported to be toxic [35-38], the DiY cross-linked tau oligomers did not cause cell death of differentiated neuroblastoma cells in the timeframe studied. Our findings suggest that DiY cross-linking on soluble dGAE promotes the formation of non-toxic, soluble tau oligomers incapable of further elongation into fibrils.

\section{Materials and Methods}

\subsection{Preparation of $d G A E$ Tau Fragment}

The preparation of recombinant dGAE (tau 297-391) has been described previously [30]. Briefly, dGAE was expressed in bacteria and, following heat treatment, purified by P11 phosphocellulose chromatography. 2-(N-morpholino)ethanesulfonic acid (MES), $\mathrm{pH}$ 6.25, was used instead of piperazine- $\mathrm{N}, \mathrm{N}^{\prime}$-bis(ethanesulfonic acid) (PIPES) in some cases. The protein fractions were eluted with $50 \mathrm{mM}$ PIPES ( $\mathrm{pH}$ 6.8) or $50 \mathrm{mM}$ MES ( $\mathrm{pH}$ 6.25), each supplemented with $1 \mathrm{mM}$ EGTA, $5 \mathrm{mM}$ ethylenediaminetetraacetic acid (EDTA), $0.2 \mathrm{mM}$ $\mathrm{MgCl}_{2}$ and $5 \mathrm{mM}$ 2-mercaptoethanol containing 0.1-1 M KCl. The peak for elution of tau, at $0.3-0.5 \mathrm{M} \mathrm{KCl}$, was dialyzed against $80 \mathrm{mM}$ PIPES buffer (pH 6.8), 1 mM EGTA, $5 \mathrm{mM}$ EDTA, $0.2 \mathrm{mM} \mathrm{MgCl} 2,5 \mathrm{mM}$ 2-mercaptoethanol, or phosphate buffer (PB) (10 mM; pH 7.4). The dGAE protein concentration. was measured using Advanced Protein Assay Reagent (Cytoskeleton, Inc. Denver, CO, USA.) using bovine serum albumin as a standard. The protein was diluted with $10 \mathrm{mM}$ phosphate buffer ( $\mathrm{pH}$ 7.4) and, for all experiments, the dGAE was used at a concentration of $100 \mu \mathrm{M}$ (Table 1). 
Table 1. dGAE conditions with and without oxidation.

\begin{tabular}{|c|c|c|c|c|c|}
\hline Label * & & + & + & + & \\
\hline Control & $100 \mu \mathrm{M} d G A E$ & Buffer & & & \\
\hline$\left[1-0.1 / \mathrm{Cu}^{2+}\right]$ & $100 \mu \mathrm{M} d G A E$ & Buffer & $10 \mu \mathrm{M} \mathrm{CuCl}_{2}$ & & \\
\hline$\left[1-10 / \mathrm{Cu}^{2+}\right]$ & $100 \mu \mathrm{M} d \mathrm{dGAE}$ & Buffer & $1 \mathrm{mM} \mathrm{CuCl}_{2}$ & & \\
\hline$\left[1-0.1 / \mathrm{Cu}^{2+} \mathrm{H}_{2} \mathrm{O}_{2}\right]$ & $100 \mu \mathrm{M} d G A E$ & Buffer & $10 \mu \mathrm{M} \mathrm{CuCl}_{2}$ & $2.5 \mathrm{mM} \mathrm{H}_{2} \mathrm{O}_{2}$ & \\
\hline$\left[1-10 / \mathrm{Cu}^{2+} \mathrm{H}_{2} \mathrm{O}_{2}\right]$ & $100 \mu \mathrm{M} d G A E$ & Buffer & $1 \mathrm{mM} \mathrm{CuCl}_{2}$ & $2.5 \mathrm{mM} \mathrm{H}_{2} \mathrm{O}_{2}$ & \\
\hline 1-1000 EDTA & $100 \mu \mathrm{M} d \mathrm{dGAE}$ & Buffer & & & $\begin{array}{c}100 \mathrm{mM} \\
\text { EDTA }\end{array}$ \\
\hline
\end{tabular}

\subsection{Preparation of Metal-Catalysed Oxidation of dGAE dGAE in $10 \mathrm{mM}$ Phosphate Buffer, $\mathrm{pH} 7.4$}

The control incubation with EDTA was used to chelate trace metals in the reaction. All the samples were either incubated at $37^{\circ} \mathrm{C}$, or at $37^{\circ} \mathrm{C}$ with agitation at $350 \mathrm{RPM}$ (Thermomixer C, Epppendorf, Hamburg, Germany). At each time point measured, the oxidation reaction was stopped using EDTA at a final concentration of $2 \mathrm{mM}$. A minimum of three independent experiments were repeated to ensure the reproducibility of the findings.

\subsection{Photo-Oxidation of $d G A E$}

dGAE at $100 \mu \mathrm{M}$ in $10 \mathrm{mM}$ PB was incubated (i) without UV-C in the dark, and (ii) in the presence of UV-C for $2 \mathrm{~h}$ using a G6T5 Germicidal 9' $6 \mathrm{~W}$ T5 UVC lamp set to $8 \mathrm{~J} / \mathrm{m}^{2} / \mathrm{s}$ (General Lamps Ltd., Buckinghamshire, UK). A minimum of three independent experiments were repeated to ensure the reproducibility of the findings.

\subsection{Fluorescence Spectroscopy}

To monitor the formation of DiY, fluorescence intensity at 400-420 nm was measured using a fluorescence spectrophotometer (Varian Ltd., Oxford, UK), using a 1-cm path length quartz cuvette (Starna Scientific, Essex, UK). Data was collected using a fluorescent excitation wavelength of $320 \mathrm{~nm}$ and emission collected between 340 and $600 \mathrm{~nm}$, with DiY peak signal expected between 400 and $420 \mathrm{~nm}$. Tyrosine fluorescence signal was monitored using an excitation wavelength of $280 \mathrm{~nm}$ and emission between 290-600, with the peak tyrosine emission observed at $305 \mathrm{~nm}$. For experiments involving $\mathrm{MCO}$, the reaction was quenched using EDTA at a final concentration of $2 \mathrm{mM}$. For all the measurements, the excitation and emission slits were both set to $10 \mathrm{~nm}$ with a scan rate set to $300 \mathrm{~nm} / \mathrm{min}$ with $2.5 \mathrm{~nm}$ data intervals and an averaging time of $0.5 \mathrm{~s}$. The photomultiplier tube detector voltage was $500 \mathrm{~V}$.

\subsection{Thioflavin S (ThS) Fluorescence Assay to Monitor dGAE Self-Assembly}

dGAE samples $(10 \mu \mathrm{L})$ were mixed and incubated for 3 min with $5 \mu \mathrm{M}$ ThS in 3-(Nmorpholino) propanesulfonic acid (MOPS) $\left(20 \mathrm{mM}, \mathrm{pH} 6.8\right.$ at $\left.37^{\circ} \mathrm{C}\right)$. Fluorescence intensity was observed using SpectraMax i3 plate reader (Molecular Devices). The readings were collected in a black, 96-well plate with a clear bottom (PerkinElmer LAS, Buckinghamshire, UK), which was sealed with an optically clear polyolefin film to avoid evaporation (StarSeal Advanced Polyolefin Film, Starlab, Milton Keynes, UK). The number of readings per well was set to 6, PMT voltage was set to high and spectra of the buffer blank were subtracted from protein fluorescence scans. The excitation wavelength was set at $440 \mathrm{~nm}$, with emission between 460 and $600 \mathrm{~nm}$, and peak emission observed at $483 \mathrm{~nm}$. Each experiment included a minimum of three independent experiments.

\subsection{Circular Dichroism (CD)}

The secondary structure of the samples was assessed using Jasco J715 CD spectrometer (Jasco, Goh-Umstadt, Germany). Each sample $(40 \mu \mathrm{L})$ was placed into a 0.2-mm path length quartz cuvette (Hellma) and scanned between 190 and $260 \mathrm{~nm}$. The CD spectra were collected in triplicate at a temperature of $21^{\circ} \mathrm{C}$. Samples were centrifuged at $20,000 \times g$ for 
30 min to pellet any fibrillar structures. The pellet was then resuspended in PB (pH7.4) before CD analysis. CD data were converted into molar ellipticity $\left(\mathrm{deg} \cdot \mathrm{cm}^{2} \cdot \mathrm{dmol}^{-1}\right.$ ) where concentrations were known.

\subsection{Negative-Stain Transmission Electron Microscopy (TEM)}

Samples $(4 \mu \mathrm{L})$ for TEM were placed on 400-mesh carbon-coated grids (Agar Scientific, Essex, UK). After 1 min incubation, excess sample was blotted using filter paper, and the grid was washed with $4 \mu \mathrm{L}$ filtered Milli-Q water and blotted. The grid was then negatively stained for $40 \mathrm{~s}$ using $4 \mu \mathrm{L}$ of filtered $2 \%(w / v)$ uranyl acetate. The excess stain was blotted with filter paper and grids left to air-dry before storage. The grids were examined using a JEOL Jem1400-plus transmission electron microscope (Jeol, MA, USA), operated at $80 \mathrm{kV}$ fitted with a Gatan Orius SC100 camera (Gatan, Leicester, UK).

\subsection{Dot Immunoblotting}

A total of $5 \mu \mathrm{L}$ of each sample was spotted onto a $0.2-\mu \mathrm{M}$ pore nitrocellulose membrane and allowed to dry for $10 \mathrm{~min}$. The membrane was incubated with blocking buffer (5\% milk in TBS containing $0.05 \%$ Tween 20 ) for 1 hour at room temperature on a rocker. The blocking buffer was next replaced with rabbit polyclonal T22 antibody that recognises oligomeric Tau (diluted 1/2000) (ABN454; Merck Millipore, Hertfordshire, UK) [39] and incubated overnight at $4{ }^{\circ} \mathrm{C}$ on a rocker. The membrane was washed six times for 5 min with washing buffer $(0.05 \%$ TBS-T), then incubated with an horse radish peroxidase-conjugated goat anti-rabbit secondary antibody for $1 \mathrm{~h}$. The membrane was washed six times for 5 min with washing buffer, then incubated with Clarity Western ECL Substrate (Bio-Rad, Hertfordshire, UK) for $1 \mathrm{~min}$ before being developed in the darkroom. A minimum of three independent experiments were conducted to ensure reproducibility of the findings.

\subsection{TEM Immunogold Labelling}

DiY was detected using immunogold electron microscopy in the oxidised dGAE sample using methods previously described [22]. Briefly, a phosphate-buffered saline, $\mathrm{pH}$ 8.2, containing 1\% BSA, $500 \mu \mathrm{L} / 1$ Tween-20, $10 \mathrm{mM} \mathrm{Na}$ EDTA, and $0.2 \mathrm{~g} / 1 \mathrm{NaN}_{3}$ (henceforth called PBS+), was used throughout. Control and oxidised dGAE samples $(4 \mu \mathrm{L})$ were placed onto 400-mesh carbon-coated grids (Agar Scientific, Essex, UK), allowed to adhere for $1 \mathrm{~min}$, and the excess sample removed using filter paper. The grids were blocked using normal goat serum (1:10 in PBS+) for $15 \mathrm{~min}$, then incubated with $(10 \mu \mathrm{g} / \mathrm{mL}$ IgG) mouse dityrosine monoclonal antibody (JaICA, Shizuoka, Japan) for $2 \mathrm{~h}$ at room temperature. The grids were rinsed three times for 2 min in PBS+, and then labelled with a $10 \mathrm{~nm}$ gold particle-conjugated goat anti-mouse IgG secondary probe (GaM10 British BioCell International, Cardiff, UK; 1:10 dilution) for $1 \mathrm{~h}$ at room temperature. The grids were rinsed five times for 2 min using PBS+, 5 times for 2 min with distilled water, then negatively stained as described above.

\subsection{Cell Death Assay}

dGAE samples, with or without $\mathrm{H}_{2} \mathrm{O}_{2}$ (Table 1), were exchanged into PB (pH 7.4) using disposable Vivaspin ${ }^{\circledR} 500$ centrifugal concentrators with an MWCO of $3 \mathrm{kDa}$ (Sartorius, Goettingen, Germany) to remove $\mathrm{Cu}^{2+}$ or $\mathrm{H}_{2} \mathrm{O}_{2}$. Differentiated SHSY5Y neuroblastoma cells were used for the cell death experiments. Firstly, undifferentiated SHSY5Y neuroblastoma cells (CRL-2266 ${ }^{\mathrm{TM}}$, ATCC, Middlesex, UK), were maintained in Dulbecco's Modified Eagle Medium: Nutrient Mixture F-12 (DMEM/F-12) (Life Technologies, Renfrew, UK), supplemented with 1\% $(v / v)$ L-glutamate (L-Glu) (Invitrogen, Inchinnan, UK), 1\% $(v / v)$ penicillin/streptomycin (Pen/Strep) (Invitrogen, Inchinnan, UK) and 10\% $(v / v)$ Fetal Calf Serum at $37{ }^{\circ} \mathrm{C}$ and $5 \% \mathrm{CO}_{2}$. The undifferentiated SHSY5Y cells were seeded to $60 \%$ confluency in a CellCarrier-96 Ultra Microplates (PerkinElmer LAS, Buckinghamshire, UK). The cells were differentiated in a medium containing 1\% fetal calf serum supplemented with $10 \mu \mathrm{M}$ trans-retinoic acid (Abcam, Cambridge, UK) for 5 days. Next, the medium was re- 
placed with serum-free media supplemented with $2 \mathrm{nM}$ brain-derived neurotrophic factor (BDNF) (Merck Millipore, Hertfordshire, UK). After 2 days in the BDNF-containing media, the media was replaced with serum-free media and the cells were treated with phosphate buffer ( $\mathrm{pH}$ 7.4) or $10 \mu \mathrm{M}$ of the selected dGAE reaction mixtures for 2 days. At the end of the incubation period, the cells were incubated with ReadyProbes Cell Viability reagent (Life Technologies, Renfrew, UK) for $15 \mathrm{~min}$. The ReadyProbes kit contains NucBlue Live reagent that stains the nuclei of live cells and propidium iodide that stains the nuclei of dead cells that have a compromised plasma membrane. The cells were imaged at $37^{\circ} \mathrm{C}$ and $5 \% \mathrm{CO}_{2}$ using Operetta CLS high-content analysis system (PerkinElmer, Beaconsfield, UK) using DAPI and TRITC filters. At least 5000 dead and live cells were analysed using the Harmony software automated analysis algorithm within the Operetta CLS high-content analysis system. A minimum of three independent experiments were performed.

\section{Results}

3.1. In Vitro Copper-Catalysed Oxidation Results in the Formation of Stable, Random Coil and ThS-Negative, Dityrosine Cross-Linked Tau Oligomers

Different oxidation conditions catalysed by metals (e.g., $\mathrm{Cu}^{2+}$ ), enzymes (e.g., horseradish peroxidase) and light (e.g., UV) have been used to generate DiY cross-linking in proteins [40]. Initially, dGAE was incubated with combinations of $\mathrm{Cu}^{2+}, \mathrm{H}_{2} \mathrm{O}_{2}$ or EDTA at $37^{\circ} \mathrm{C}$ as shown in Table 1 . DiY is observed as a fluorescent signal with an emission peak between 400-420 $\mathrm{nm}$ [22]. Fluorescence spectroscopy showed that dGAE incubated with $\mathrm{Cu}^{2+}$ at a ratio of 1:10 with $2.5 \mathrm{mM} \mathrm{H}_{2} \mathrm{O}_{2}\left[1-10 / \mathrm{Cu}^{2+} \mathrm{H}_{2} \mathrm{O}_{2}\right]$ showed the highest signal at $405 \mathrm{~nm}$ following $15 \mathrm{~min}$ of incubation, while $\mathrm{Cu}^{2+}$ alone at $1: 10\left[1-10 / \mathrm{Cu}^{2+}\right]$ also showed a lower, but significant signal (Figure 1A). The control sample (buffer only), dGAE incubated with $\mathrm{Cu}^{2+}$ at a ratio of 1:0.1 alone [1-0.1/ $\mathrm{Cu}^{2+}$ ] or additional $2.5 \mathrm{mM} \mathrm{H}_{2} \mathrm{O}_{2}$ (1-0.1/ $\mathrm{Cu}^{2+} \mathrm{H}_{2} \mathrm{O}_{2}$ ) and dGAE with EDTA alone at 1:1000 ratio (1-1000 EDTA) showed no signal intensity at $405 \mathrm{~nm}$ (Figure 1A). This result shows that incubation with $\mathrm{Cu}^{2+}$ results in the rapid formation of DiY, that is greater in the presence of $\mathrm{H}_{2} \mathrm{O}_{2}$. The presence of DiY was confirmed in the [1-10/ $\mathrm{Cu}^{2+} \mathrm{H}_{2} \mathrm{O}_{2}$ ] sample using TEM immunogold labelling using anti-DiY antibody (Figure 1B). The increase in DiY was matched by a decrease in tyrosine signal at $305 \mathrm{~nm}$ for $\left[1-10 / \mathrm{Cu}^{2+} \mathrm{H}_{2} \mathrm{O}_{2}\right]$ and $\left[1-10 / \mathrm{Cu}^{2+}\right]$ and a strong signal arising from DiY could also be observed in the $\left[1-10 / \mathrm{Cu}^{2+} \mathrm{H}_{2} \mathrm{O}_{2}\right]$ sample at $400 \mathrm{~nm}$ (Figure 1C). The [1-0.1/ $\left.\mathrm{Cu}^{2+}\right]$ and $\left[1-0.1 / \mathrm{Cu}^{2+} \mathrm{H}_{2} \mathrm{O}_{2}\right]$ samples that showed no signal for DiY after $15 \mathrm{~min}$ incubation, but showed a slight decrease in the tyrosine fluorescence intensity consistent with a conformational change in dGAE (Figure 1C). After $24 \mathrm{~h}$, we observed that the DiY signal intensity reaches a plateau after about $4 \mathrm{~h}$ incubation in both the $\left[1-10 / \mathrm{Cu}^{2+}\right]$ and $\left[1-10 / \mathrm{Cu}^{2+} \mathrm{H}_{2} \mathrm{O}_{2}\right]$ samples (Figure 1D). Together, these data reveal that tau, similar to $\mathrm{A} \beta[22,41]$ and $\alpha$-synuclein [23], rapidly forms DiY in an MCO environment and that this depends on $\mathrm{Cu}^{2+}$ concentration. Even in the absence of $\mathrm{H}_{2} \mathrm{O}_{2}$, supra-equimolar level $\mathrm{Cu}^{2+}$ was able to efficiently induce DiY in dGAE.

Thioflavin S (ThS) fluorescence assay was used to investigate the assembly of dGAE under the various conditions. ThS fluorescence intensity increased only in the 1-1000 EDTA sample suggesting that dGAE assembles only in the presence of the metal chelator, while all other conditions showed very low intensity fluorescence at $483 \mathrm{~nm}$ up to six days suggesting that dGAE does not assemble in the absence of agitation (Figure 1E). dGAE samples incubated with lower concentrations of EDTA (1-10 and 1-100) did not show ThS fluorescence (data not shown). 

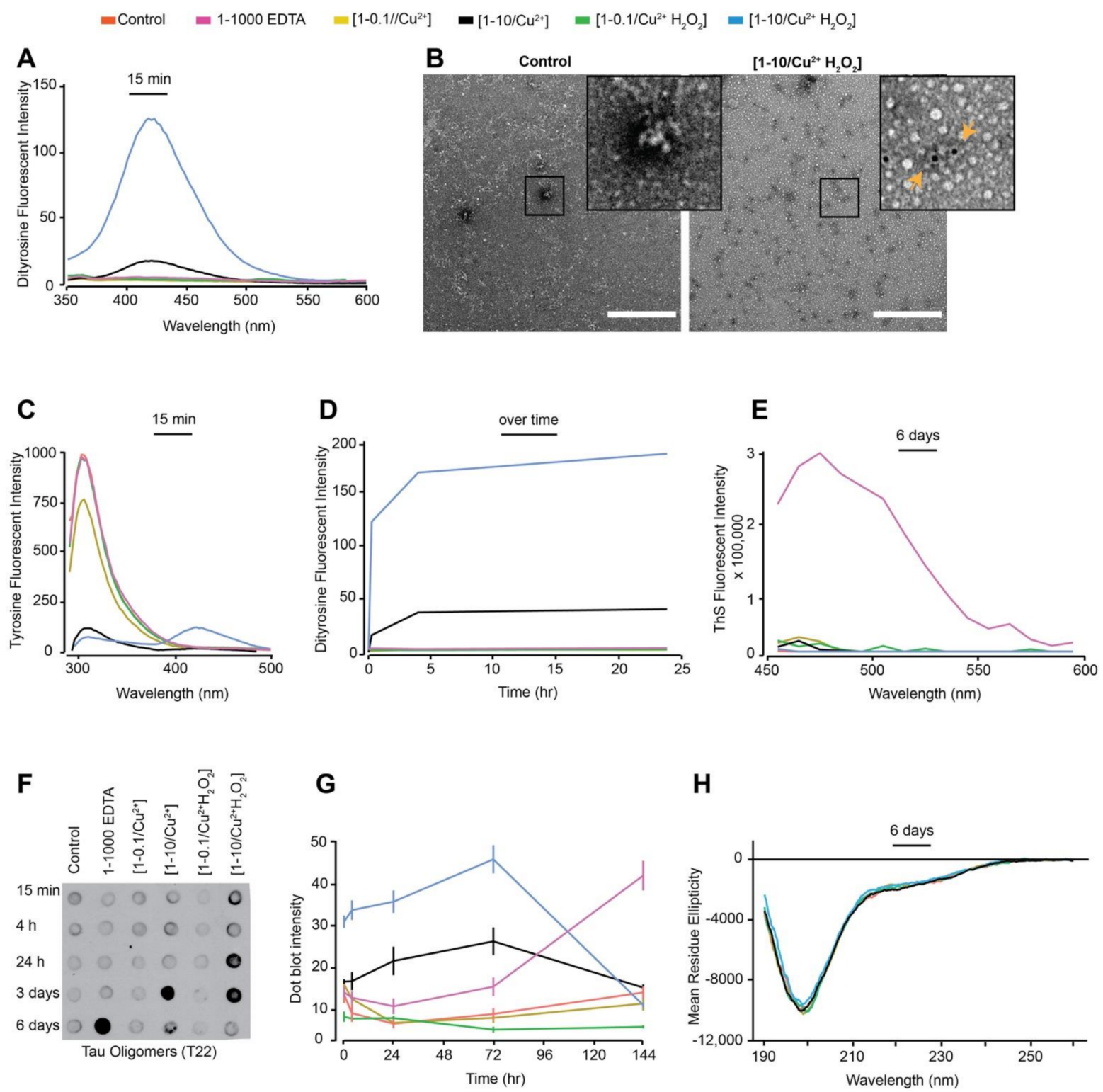

Figure 1. Freshly prepared dGAE $(100 \mu \mathrm{M})$ was incubated at $37^{\circ} \mathrm{C}$ without agitation, alone (control), with $10 \mu \mathrm{M} \mathrm{CuCl} 2$ [1-0.1/ $\left.\mathrm{Cu}^{2+}\right], 1 \mathrm{mM} \mathrm{CuCl}_{2}\left[1-10 / \mathrm{Cu}^{2+}\right], 10 \mu \mathrm{M} \mathrm{CuCl}_{2}$ in combination with $2.5 \mathrm{mM} \mathrm{H}_{2} \mathrm{O}_{2}$ [1-0.1// $\left.\mathrm{Cu}^{2+} \mathrm{H}_{2} \mathrm{O}_{2}\right], 1 \mathrm{mM} \mathrm{CuCl}_{2}$ in combination with $2.5 \mathrm{mM} \mathrm{H}_{2} \mathrm{O}_{2}$ [1-10/ $\mathrm{Cu}^{2+} \mathrm{H}_{2} \mathrm{O}_{2}$ ) or with $100 \mathrm{mM}$ EDTA (1-1000 EDTA) (see Table 1 for condition details). DiY signal was collected 15 min post-incubation using fluorescent excitation/emission $320 \mathrm{~nm} / 340-600 \mathrm{~nm}$, with DiY peak signal observed between 400-420 nm (A). The presence of DiY in dGAE was confirmed using TEM immunogold-labelling where black dots indicate DiY detected with mouse anti-DiY antibody (see orange arrows in the insert). Scale bar, $500 \mathrm{~nm}$. (B). Tyrosine signal was collected at $15 \mathrm{~min}$ of incubation using an excitation/emission $280 \mathrm{~nm} / 290-500 \mathrm{~nm}$, with peak tyrosine signal observed at $305 \mathrm{~nm}$ (C). DiY signal was collected again at $4 \mathrm{~h}$ and $24 \mathrm{~h}$ to follow DiY formation over $24 \mathrm{~h}$ duration (D). ThS fluorescence intensity was conducted after six days incubation to observe the degree of self-assembly using excitation/emission of 440/460-600 nm (E). Immunoblotting using T22 antibody identifies the presence of tau oligomers (F). Quantification of the immunoblot signal suggest a high level of tau oligomers early-on in the [1-0.1// $\left.\mathrm{Cu}^{2+} \mathrm{H}_{2} \mathrm{O}_{2}\right]$ and $\left[1-0.1 / / \mathrm{Cu}^{2+}\right]$ samples $(\mathrm{G})$. CD analysis at six days post-incubation showed that all the samples had a comparable level of random-coil secondary structure $(\mathbf{H})$.

Immunoblotting was conducted using the tau oligomer-specific polyclonal antibody, T22 [39], to learn more about the conformation of dGAE under different conditions. Interestingly, immunoblots showed an increasing level of tau oligomers from $4 \mathrm{~h}$ to three days in the high concentration copper-containing samples that also developed DiY. Samples in which DiY did not form showed a much slower increase in T22 intensity (Figure 1F,G). 
[1-10/ $\left.\mathrm{Cu}^{2+} \mathrm{H}_{2} \mathrm{O}_{2}\right]$, which favours rapid DiY formation, showed strong T22 binding affinity as early as 15 min post-incubation which remained intense up to three days. The $\left[1-10 / \mathrm{Cu}^{2+}\right]$ sample showed strongest antibody binding intensity at three days (Figure $1 F, G)$. The T22 binding affinity for both the $\left[1-10 / \mathrm{Cu}^{2+}\right]$ and $\left[1-10 / \mathrm{Cu}^{2+} \mathrm{H}_{2} \mathrm{O}_{2}\right]$ samples had decreased after six days, suggesting that the DiY formation facilitates the formation of T22-positive but ThS negative tau oligomers and prolonged their half-life. The disappearance of the T22 signal after this time may be due to further oxidation of the dGAE or the formation of larger oligomeric assemblies with reduced affinity for T22.

We have previously shown that soluble dGAE exists in a random-coil conformation by circular dichroism (CD), and transitions to $\beta$-sheet conformation during self-assembly, accompanied by a reduction in random coil signal [30]. Moreover, tau oligomers have been described as being insoluble with $\beta$-sheet secondary structure [35]. We used CD to interrogate the secondary structure of the dGAE under the different conditions, and this revealed that all the samples remained in a random-coil conformation with an identical CD spectrum (Figure 1H). Given that tau exists mostly in a random-coil conformation, CD spectra analysis can be conducted by resuspending a pellet obtained from high-speed centrifugation of the dGAE samples in order to investigate the presence of a $\beta$-sheet signal [30]. However, none of the samples, except the 1-1000 EDTA reaction, formed a significant pellet after centrifugation, which precluded the search for $\beta$-sheet signal in these samples. The high concentration of EDTA in the 1-1000 EDTA reaction led to a significant increase in the high-tension signal during CD spectra collection (not shown). Therefore, CD could not be conducted on the 1-1000 EDTA sample. Together, the CD data suggests that oxidation causes no obvious change in secondary structure or solubility of the dGAE under any of the conditions, except in high EDTA.

TEM negative staining was used to examine the morphology of dGAE in the different samples (Figure 2). At $0 \mathrm{~h}$, dGAE under all conditions showed the typical morphology of unassembled dGAE [30]. By six days, however, the control sample revealed the presence of small assemblies, which are mostly short rod-like particles, likely on the path to becoming mature fibrils. The 1-1000 EDTA sample showed a combination of short and long fibrils, consistent with the ThS data indicating self-assembly. [1-0.1/ $\left.\mathrm{Cu}^{2+}\right]$ and $\left[1-0.1 / \mathrm{Cu}^{2+} \mathrm{H}_{2} \mathrm{O}_{2}\right]$ samples both showed small assemblies and short fibrils. Interestingly, the $\left[1-10 / \mathrm{Cu}^{2+}\right]$ and [1-10/ $\mathrm{Cu}^{2+} \mathrm{H}_{2} \mathrm{O}_{2}$ ] samples, which both form DiY, showed very few short fibres and large amorphous aggregates. In summary, TEM data revealed that only the 1-1000 EDTA reaction goes on to form long tau filaments after six days incubation, while the other samples form assemblies that are largely non-fibrillar and consistent with the observation of very low ThS fluorescence. The data suggest that DiY cross-linking results in the oligomerisation and stabilisation of dGAE into large oligomers that are rich in random-coil.

\subsection{Oxidation Resulting in DiY Cross-Linking Halts Elongation of Tau Oligomers to Fibrils Following Agitation}

We have previously shown that the agitation of dGAE enhances its self-assembly into filaments [30] shortening the incubation time to $24 \mathrm{~h}$. Therefore, $100 \mu \mathrm{M}$ dGAE was prepared as described earlier (Table 1), except that the samples were incubated at $37{ }^{\circ} \mathrm{C}$ in a thermomixer set to oscillate at $350 \mathrm{RPM}$ to facilitate assembly. The $37{ }^{\circ} \mathrm{C}$ /350 RPM condition resulted in DiY formation in both the $\left[1-10 / \mathrm{Cu}^{2+}\right]$ and $\left[1-10 / \mathrm{Cu}^{2+}\right.$ $\mathrm{H}_{2} \mathrm{O}_{2}$ ] samples over time (Figure 3A,C). However, the DiY signal was slightly higher than that observed in similar reaction mixtures incubated without agitation (Figure 1A,D). As with the result obtained with the quiescent condition (Figure 1C), agitation led to a decrease in the tyrosine signal in the $\left[1-10 / \mathrm{Cu}^{2+}\right]$ and $\left[1-10 / \mathrm{Cu}^{2+} \mathrm{H}_{2} \mathrm{O}_{2}\right]$ samples with incubation time (Figure 3B). Agitation has been shown to enhance assembly and, as expected, all conditions except the $\left[1-10 / \mathrm{Cu}^{2+}\right]$ and $\left[1-10 / \mathrm{Cu}^{2+} \mathrm{H}_{2} \mathrm{O}_{2}\right]$ led to an increase in ThS intensity over time (Figure 3D). The $\left[1-10 / \mathrm{Cu}^{2+}\right]$ and $\left[1-10 / \mathrm{Cu}^{2+} \mathrm{H}_{2} \mathrm{O}_{2}\right]$ conditions did not show any increase in ThS fluorescence even after $150 \mathrm{~h}$. These data support the view that oxidation, which results in formation of DiY, inhibits further elongation (Figure 1E), and suggests that 
those reactions in which DiY forms $\left(\left[1-10 / \mathrm{Cu}^{2+}\right]\right.$ and $\left.\left[1-10 / / \mathrm{Cu}^{2+} \mathrm{H}_{2} \mathrm{O}_{2}\right]\right)$ have reduced self-assembly properties.

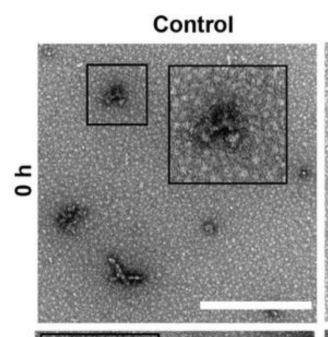

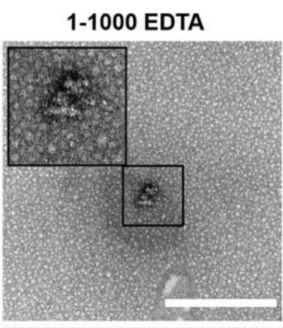

$\left[1-0.1 / \mathrm{Cu}^{2+}\right]$
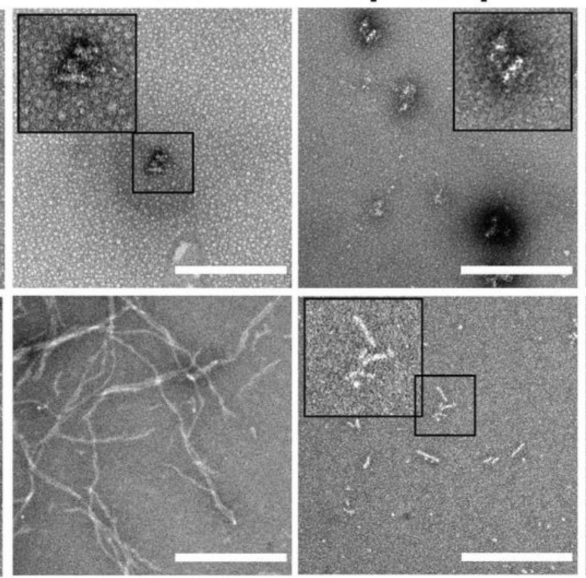

$\left[1-10 / \mathrm{Cu}^{2+}\right]$
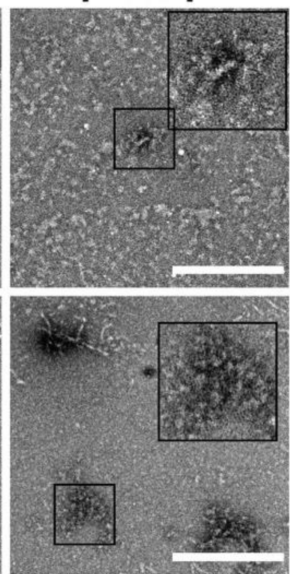

$\left[1-0.1 / \mathrm{Cu}^{2+} \mathrm{H}_{2} \mathrm{O}_{2}\right]$
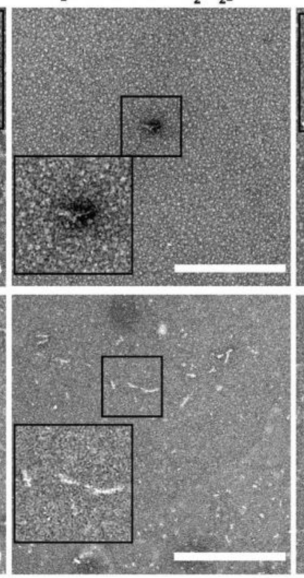

$\left[1-10 / \mathrm{Cu}^{2+} \mathrm{H}_{2} \mathrm{O}_{2}\right]$
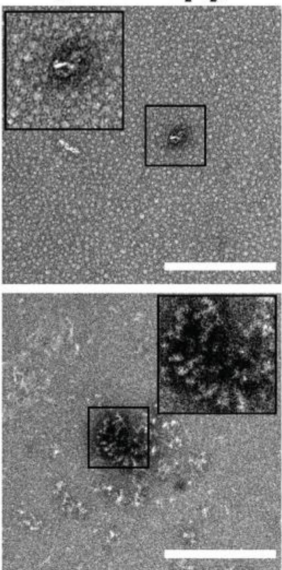

Figure 2. Freshly prepared dGAE $(100 \mu \mathrm{M})$ was incubated at $37^{\circ} \mathrm{C}$ without agitation, alone (control), with $10 \mu \mathrm{M} \mathrm{CuCl} 2$ [1-0.1/ $\mathrm{Cu}^{2+}$ ], $1 \mathrm{mM} \mathrm{CuCl}_{2}\left[1-10 / \mathrm{Cu}^{2+}\right], 10 \mu \mathrm{M} \mathrm{CuCl}_{2}$ in combination with $2.5 \mathrm{mM} \mathrm{H}_{2} \mathrm{O}_{2}$ [1-0.1/ $\left.\mathrm{Cu}^{2+} \mathrm{H}_{2} \mathrm{O}_{2}\right], 1 \mathrm{mM} \mathrm{CuCl}{ }_{2}$ in combination with $2.5 \mathrm{mM} \mathrm{H}_{2} \mathrm{O}_{2}$ [1-10/ $\mathrm{Cu}^{2+} \mathrm{H}_{2} \mathrm{O}_{2}$ ] or with $100 \mathrm{mM}$ EDTA [1-1000 EDTA]. TEM imaging of all the samples at $0 \mathrm{~h}$ revealed small, round assemblies (Top row). At six days, the control, $\left[1-0.1 / \mathrm{Cu}^{2+}\right]$ and $\left[1-0.1 / \mathrm{Cu}^{2+} \mathrm{H}_{2} \mathrm{O}_{2}\right]$ samples show the presence of small, short fibrils. The $\left[1-10 / \mathrm{Cu}^{2+}\right]$ and $\left[1-10 / / \mathrm{Cu}^{2+} \mathrm{H}_{2} \mathrm{O}_{2}\right]$ samples showed small and large oligomeric assemblies with the occasional presence of short fibrils. The 1-1000 EDTA samples revealed short and long fibrils. Scale bar $=500 \mathrm{~nm}$.

T22 immunoblotting showed that $\left[1-10 / \mathrm{Cu}^{2+}\right]$ and $\left[1-10 / \mathrm{Cu}^{2+} \mathrm{H}_{2} \mathrm{O}_{2}\right]$ at $37^{\circ} \mathrm{C} / 350 \mathrm{RPM}$ showed increased intensity at early time points which remained high up to three days incubation (Figure 3E,F). The extent of T22 binding was particularly high in the $\left[1-10 / \mathrm{Cu}^{2+}\right.$ $\left.\mathrm{H}_{2} \mathrm{O}_{2}\right] 37^{\circ} \mathrm{C} / 350 \mathrm{RPM}$ sample (Figure 3F). These data support the view that DiY crosslinking promotes the formation of long-lived, soluble tau oligomers that show negligible ThS fluorescence.

CD showed the expected reduction in random coil signal at $195 \mathrm{~nm}$ over time as the dGAE assembles under all conditions except for samples containing $\left[1-10 / \mathrm{Cu}^{2+}\right]$ and $\left[1-10 / \mathrm{Cu}^{2+} \mathrm{H}_{2} \mathrm{O}_{2}\right]$ (Figure 3G). Samples were centrifuged to separate the pellet and supernatant, and the control, [1-0.1/ $\left.\mathrm{Cu}^{2+}\right]$ and $\left[1-0.1 / \mathrm{Cu}^{2+} \mathrm{H}_{2} \mathrm{O}_{2}\right]$ samples showed a small minimum at $228 \mathrm{~nm}$ consistent with previous observations attributed to elongated $\beta$-sheet [30] (Figure 3H). However, even after the $30 \mathrm{~min}$ high-speed centrifugation, the [1-10 $\left.\mathrm{Cu}^{2+}\right]$ and [1-10/ $\mathrm{Cu}^{2+} \mathrm{H}_{2} \mathrm{O}_{2}$ ] samples did not form pellets. CD could not be obtained from the 1-1000 EDTA sample due to the EDTA concentration in the sample that caused an increase in the high-tension signal, which makes the result unreliable. CD spectra analysis agrees with the ThS assay results in showing that the ThS-positive dGAE reactions are $\beta$-sheet positive, while the ThS-negative samples are random-coil rich.

TEM negative staining at $0 \mathrm{~h}$ showed the typical morphology of unassembled dGAE for all samples (Figure 4). However, following six days incubation at $37^{\circ} \mathrm{C} / 350 \mathrm{RPM}$, all the samples except the $\left[1-10 / \mathrm{Cu}^{2+}\right]$ and $\left[1-10 / \mathrm{Cu}^{2+} \mathrm{H}_{2} \mathrm{O}_{2}\right]$ samples, formed filaments consistent with the results from ThS fluorescence (Figure 3D). The 1-1000 EDTA sample showed the highest density of fibres, comprised of both short and long, twisted fibres. In contrast, oxidised DiY cross-linked [1-10/ $\left.\mathrm{Cu}^{2+}\right]$ and $\left[1-10 / \mathrm{Cu}^{2+} \mathrm{H}_{2} \mathrm{O}_{2}\right]$ dGAE showed mainly amorphous oligomeric aggregates (Figure 2). Altogether, these data suggest that MCO-induced DiY cross-linking promotes the assembly and stabilisation of the dGAE into ThS-negative, random-coil rich, oligomeric assemblies and prevents their further elongation into filaments. Prolonged incubation up to four weeks did not result in fibrillisation (data not shown), indicating that the oxidation results in stable oligomeric species. 
$=\left[1-0.1 / / \mathrm{Cu}^{2+}\right]=\left[1-10 / \mathrm{Cu}^{2+}\right]=\left[1-0.1 / \mathrm{Cu}^{2+} \mathrm{H}_{2} \mathrm{O}_{2}\right]=\left[1-10 / \mathrm{Cu}^{2+} \mathrm{H}_{2} \mathrm{O}_{2}\right]$

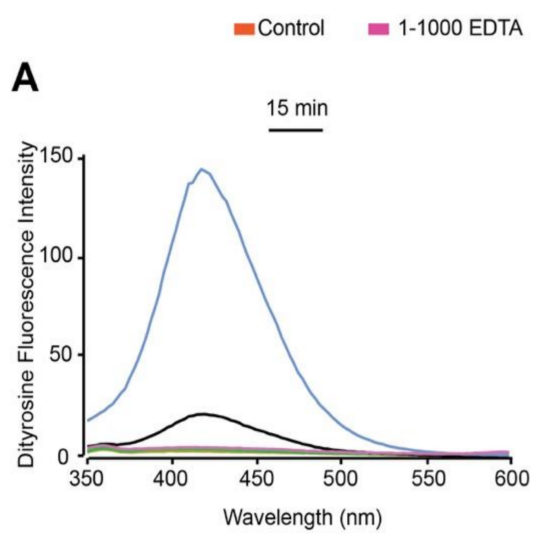

A

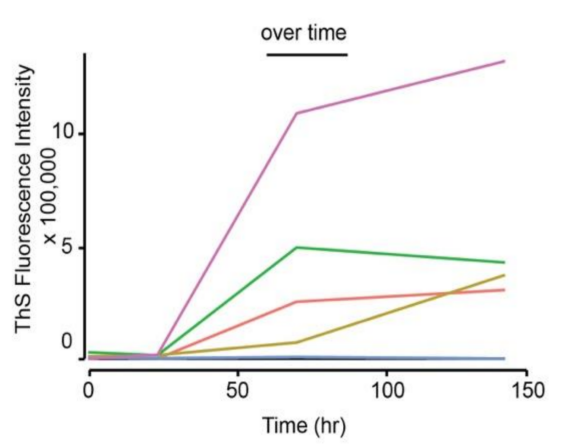

G

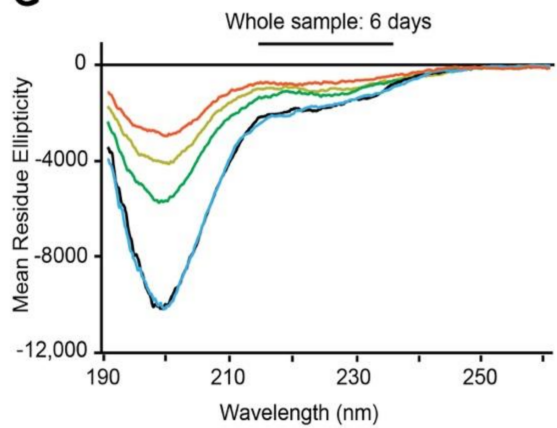

H

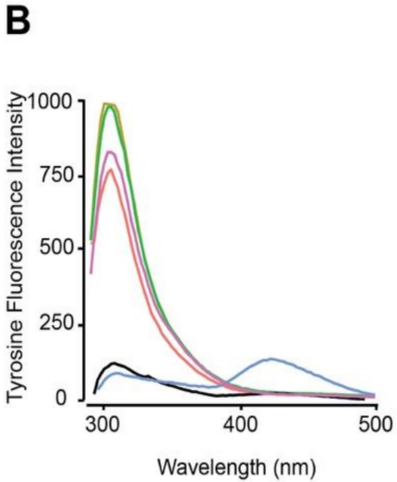

E

C

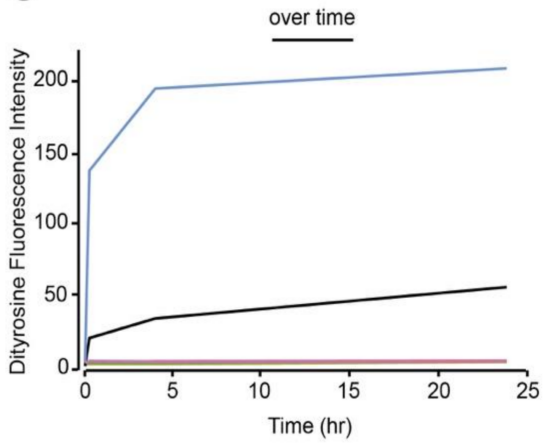

$\mathbf{F}$
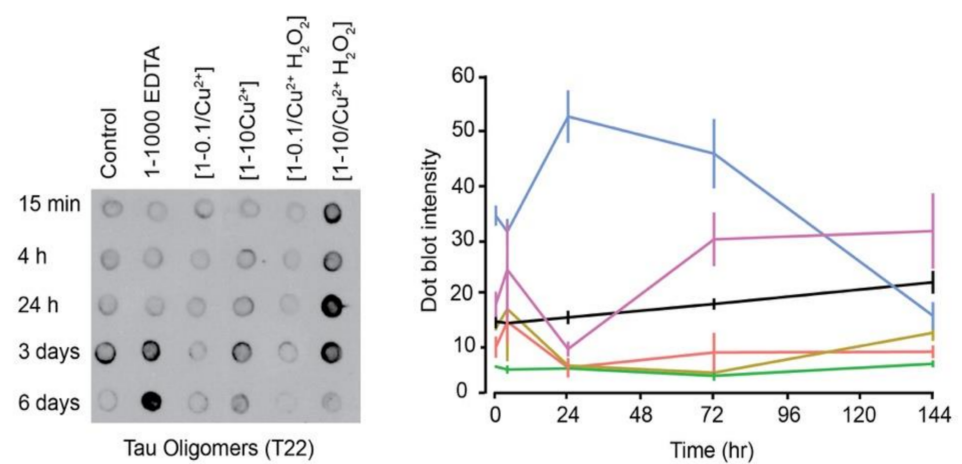

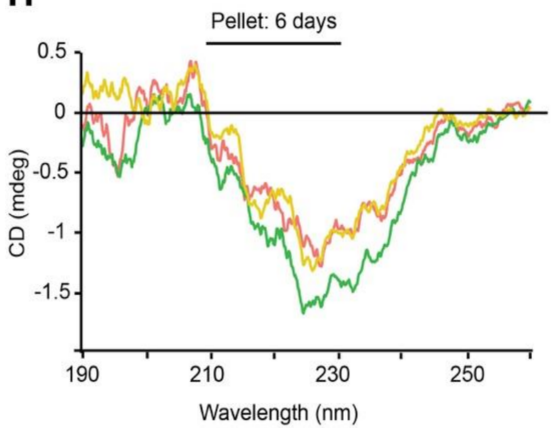

Figure 3. Freshly prepared control, [1-0.1/ $\left.\mathrm{Cu}^{2+}\right]$, [1-10 $\left.\mathrm{Cu}^{2+}\right]$, [1-0.1/ $\left.\mathrm{Cu}^{2+} \mathrm{H}_{2} \mathrm{O}_{2}\right],\left[1-10 / \mathrm{Cu}^{2+} \mathrm{H}_{2} \mathrm{O}_{2}\right]$ and 1-1000 EDTA samples were incubated at $37^{\circ} \mathrm{C} / 350 \mathrm{RPM}$. DiY fluorescence signal was collected 15 min post-incubation, showing a significant increase in intensity at $410-420 \mathrm{~nm}$ in the $\left[1-10 / \mathrm{Cu}^{2+}\right]$ and $\left[1-10 / \mathrm{Cu}^{2+} \mathrm{H}_{2} \mathrm{O}_{2}\right]$ samples (A). Tyrosine signal was collected at $15 \mathrm{~min}$ of incubation showing a significant decrease in intensity over time for the 1-10 and 1-10/ $\mathrm{H}_{2} \mathrm{O}_{2}$ samples (B). DiY signal was collected at $4 \mathrm{~h}$ and $24 \mathrm{~h}$ to follow DiY formation over $24 \mathrm{~h}$ duration, which showed that DiY reaches plateau about $4 \mathrm{~h}$ after incubation in the $\left[1-10 / \mathrm{Cu}^{2+} \mathrm{H}_{2} \mathrm{O}_{2}\right]$, while it continues to increase in the $\left[1-10 / \mathrm{Cu}^{2+}\right](\mathrm{C})$. ThS fluorescence was collected over a time course of six days to assess the degree of self-assembly over time (D). Immunoblotting using T22 antibody reveals the presence of Tau oligomers (E). Quantification of the dot blotting signal revealed a high level of Tau oligomers early-on in the [1:10/ $\left.\mathrm{Cu}^{2+} \mathrm{H}_{2} \mathrm{O}_{2}\right]$ reaction, followed by a gradual increase in the oligomer levels in the $\left[1: 10 / \mathrm{Cu}^{2+}\right]$ reaction $(\mathbf{F}) . \mathrm{CD}$ at six days showed a reduction in the level of random-coil in control, $\left[1: 0.1 / \mathrm{Cu}^{2+}\right],\left[1: 0.1 / \mathrm{Cu}^{2+}\right.$ $\left.\mathrm{H}_{2} \mathrm{O}_{2}\right]$ samples when compared to the $\left[1: 10 / \mathrm{Cu}^{2+}\right]$ and $\left[1: 10 / \mathrm{Cu}^{2+} \mathrm{H}_{2} \mathrm{O}_{2}\right]$ samples $(\mathbf{G})$. The $\mathrm{CD}$ spectra for the pellet from the control, $\left[1: 0.1 / \mathrm{Cu}^{2+}\right],\left[1: 0.1 / \mathrm{Cu}^{2+} \mathrm{H}_{2} \mathrm{O}_{2}\right]$ samples revealed the presence of a minimum at $228 \mathrm{~nm}(\mathbf{H})$. 

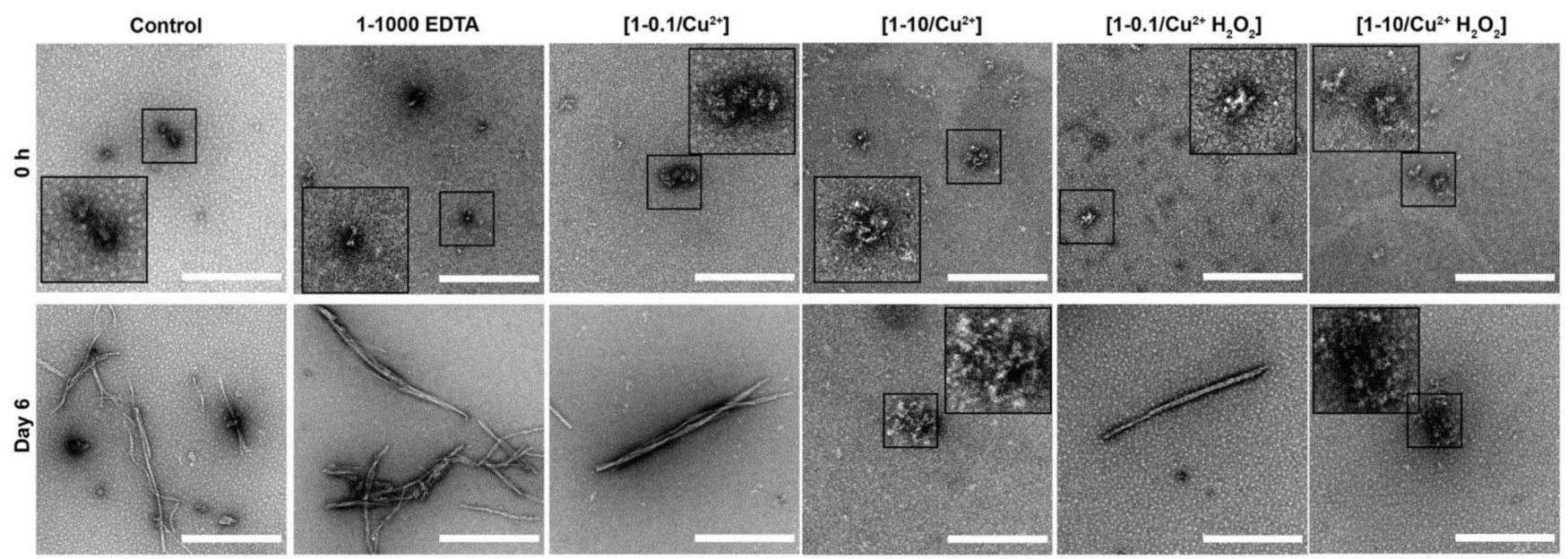

Figure 4. Freshly prepared control, $\left[1-0.1 / \mathrm{Cu}^{2+}\right],\left[1-10 / \mathrm{Cu}^{2+}\right],\left[1-0.1 / \mathrm{Cu}^{2+} \mathrm{H}_{2} \mathrm{O}_{2}\right],\left[1-10 / \mathrm{Cu}^{2+} \mathrm{H}_{2} \mathrm{O}_{2}\right]$ and 1-1000 EDTA samples were incubated at $37^{\circ} \mathrm{C} / 350 \mathrm{RPM}$. TEM imaging of all the samples at $0 \mathrm{~h}$ revealed small, round assemblies (Top row). At six days post-incubation, the control, [1-0.1/ $\left.\mathrm{Cu}^{2+}\right]$ and [1-0.1/ $\mathrm{Cu}^{2+} \mathrm{H}_{2} \mathrm{O}_{2}$ ] samples showed both short and long fibrils. The [1-10/Cu $\left.{ }^{2+}\right]$ and $\left[1-10 / \mathrm{Cu}^{2+} \mathrm{H}_{2} \mathrm{O}_{2}\right.$ ] samples showed mostly small and large amorphous assemblies. The 1-1000 EDTA samples revealed mature, twisted filaments. Scale bar, $500 \mathrm{~nm}$.

3.3. DiY Formation before the Onset of Assembly Promotes the Formation of Tau Oligomers but Inhibits Elongation into Fibrils

We have shown that DiY cross-linking, induced by supra-equimolar $\mathrm{Cu}^{2+}$ and $\mathrm{CuCl}_{2}$ with $\mathrm{H}_{2} \mathrm{O}_{2}$, prevents elongation of dGAE into filaments. Previous studies have shown that $\mathrm{Cu}^{2+}$ influences tau self-assembly [42,43]. Therefore, to evaluate the impact of DiY on dGAE assembly without the influence of agitation, temperature or $\mathrm{Cu}^{2+}, \mathrm{UV}$ photo-oxidation was performed at a low temperature and without agitation, to induce DiY cross-linking. We first optimised the UV exposure duration to induce DiY formation in dGAE. UV exposure for $2 \mathrm{~h}$ at $4{ }^{\circ} \mathrm{C}$ resulted in the formation of DiY in a freshly prepared dGAE sample $(+2 \mathrm{~h}$ UV) (Figure 5A). DiY intensity was $~ 5$-fold lower than the DiY signal observed after 15 min in the $\left[1-10 / \mathrm{Cu}^{2+} \mathrm{H}_{2} \mathrm{O}_{2}\right]$ incubated at $37^{\circ} \mathrm{C} / 350 \mathrm{RPM}$ (Figure $3 \mathrm{~A}$ ). When the same dGAE sample incubated with UV for $2 \mathrm{~h}$ was further incubated at $37^{\circ} \mathrm{C} / 350 \mathrm{RPM}$ for six days, the level of DiY doubled (+ 2 h UV /6 d) (Figure 5A). ThS fluorescence assay indicated that the UV exposure did not result in dGAE self-assembly after six days incubation following 2-h UV exposure similar to the control (Figure 5B). Immunoblotting using the T22 antibody showed that the 2-h UV-exposure results in the formation of T22-positive oligomers which remain after six days incubation (Figure 5C). Therefore, $2 \mathrm{~h}$ UV exposure resulted in the formation of DiY, inhibition of assembly, and stabilisation of T22 positive oligomers, which were maintained for six days after UV incubation.

To investigate whether addition of EDTA can modulate the DiY formation and assembly of UV incubated dGAE, a freshly prepared 1-1000 EDTA sample was incubated for $2 \mathrm{~h}$ under UV [1-1000 EDTA +UV] and compared to EDTA without UV [1-1000 EDTA] (Figure 5D). A DiY signal was observed after a $2 \mathrm{~h}$ UV incubation of dGAE in the presence of EDTA and increased after 6 days agitation at $37^{\circ} \mathrm{C}$, while those unexposed to UV did not form DiY (Figure 5D). As expected, the sample that was not exposed to UV showed significant ThS fluorescence after six days incubation at $37^{\circ} \mathrm{C} / 350 \mathrm{RPM}$ and only a very small signal was observed for the six-day EDTA dGAE sample incubated in UV (Figure 5E). Electron micrographs showed that the expected filaments were present in dGAE incubated with EDTA (Figure 5F) but the UV-exposed EDTA sample contained only amorphous assemblies even after six days of incubation at $37^{\circ} \mathrm{C} / 350$ RPM (Figure 5G). Thus, DiY formation before the onset of assembly inhibits or substantially delays the assembly of the dGAE into filaments. 
- Control $=[+2 \mathrm{~h} U V]=[+2 \mathrm{~h} U \mathrm{VV} / 6 \mathrm{~d}]$

A

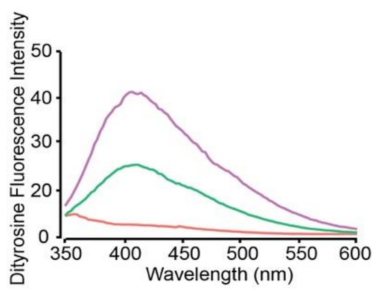

- 1-1000 EDTA

- 1-1000 EDTA +

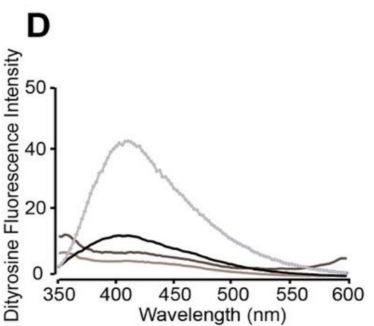

E

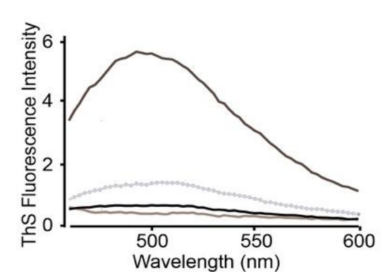

B

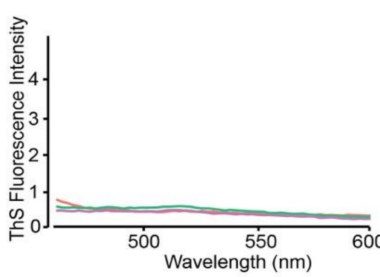

- 1-1000 EDTA $6 \mathrm{~d}$

1-1000 EDTA +UV/6d
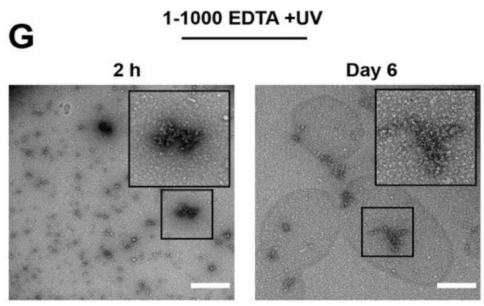

C
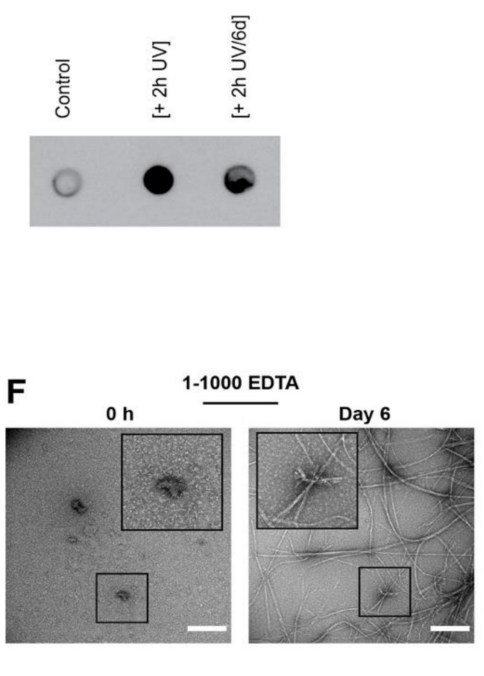

Figure 5. Freshly prepared dGAE samples $(100 \mu \mathrm{M})$ were incubated without UV (control) or in the presence of UV for $2 \mathrm{~h}$ at $4{ }^{\circ} \mathrm{C}[+2 \mathrm{~h} \mathrm{UV}]$, and the $2 \mathrm{~h}$ UV-exposed sample was further incubated for six days at $37^{\circ} \mathrm{C} / 350 \mathrm{RPM}[+2 \mathrm{~h} \mathrm{UV} / 6 \mathrm{~d}]$. Measurement of DiY signal over time revealed the induction of DiY by the UV exposed sample (A). ThS fluorescence assay showed no fluorescence intensity indicating there was no assembly in any of the samples (B). Immunoblotting using the T22 antibody, suggested the presence of a large quantity of tau oligomers in the UV-exposed samples compared to control (C). Freshly prepared 1-1000 EDTA samples were incubated without UV for $2 \mathrm{~h}$ or 6 days at $37^{\circ} \mathrm{C} / 350 \mathrm{RPM}(1-1000$ EDTA $6 \mathrm{~d})$ and with UV for $2 \mathrm{~h}(1-1000$ EDTA $+\mathrm{UV})$ or $2 \mathrm{~h} \mathrm{UV}$ followed by 6 days incubation at $37^{\circ} \mathrm{C} / 350$ RPM (1-1000 EDTA +UV/ $\left.6 \mathrm{~d}\right)$. DiY signal was collected at each time point (D), followed by ThS fluorescence assay, which suggested assembly in the 1-1000 EDTA $6 \mathrm{~d}$ sample and not the others (E). TEM imaging at $0 \mathrm{~h}$ revealed small, round assemblies in the $0 \mathrm{~h}$ [1-1000 EDTA] sample, which assembled into long mature fibrils after 6 days incubation at $37^{\circ} \mathrm{C} / 350$ RPM (F). The 1-1000 EDTA + UV samples revealed both small and large clumped assemblies, which remained largely unchanged even after 6 days of incubation at $37^{\circ} \mathrm{C} / 350 \mathrm{RPM}$. Scale bar, $500 \mathrm{~nm}(\mathbf{G})$.

\subsection{DiY Cross-Linked Tau Oligomers Do Not Cause Cell Death}

The evidence for neurotoxic assemblies formed from tau remains unclear [5]. Toxic tau oligomers have been described as having $\beta$-sheet secondary structure [35] while nontoxic, $\beta$-sheet negative tau oligomers have also been described $[44,45]$. To investigate and compare the toxicity of non-oxidised and DiY dGAE, we utilised differentiated human neuroblastoma SHSY5Y cells $[14,46]$ and assessed the cell death using the ReadyProbes Cell Viability Imaging Kit. We have established that incubation with $\mathrm{Cu}^{2+}$ and $\mathrm{Cu}^{2+}$ with $\mathrm{H}_{2} \mathrm{O}_{2}$, as well as $2 \mathrm{~h} \mathrm{UV}$, induce significant DiY cross-linking resulting in long-lived amorphous oligomers (Figures 1-5). Differentiated SHSY5Y cells were incubated for $72 \mathrm{~h}$ with phosphate buffer (as vehicle control) or $10 \mu \mathrm{M} 2 \mathrm{~h}$ UV-exposed dGAE, $10 \mu \mathrm{M}$ 3 days $/ 37^{\circ} \mathrm{C}$-incubated dGAE control, $\left[1-10 / \mathrm{Cu}^{2+}\right]$ sample and $\left[1-10 / \mathrm{Cu}^{2+} \mathrm{H}_{2} \mathrm{O}_{2}\right.$ ] sample 
and incubation for $1 \mathrm{~h}$ with $2 \mathrm{mM} \mathrm{H}_{2} \mathrm{O}_{2}$ was used as a positive control (Figure 6). No significant cell death was detected for any of the conditions except for the positive control. We have previously shown that soluble dGAE, even at higher concentration, was not toxic to differentiated neuroblastoma cells [47]. These data revealed that the DiY cross-linked, ThS and $\beta$-sheet negative soluble tau oligomers described here do not result in cell death under the incubation conditions studied.

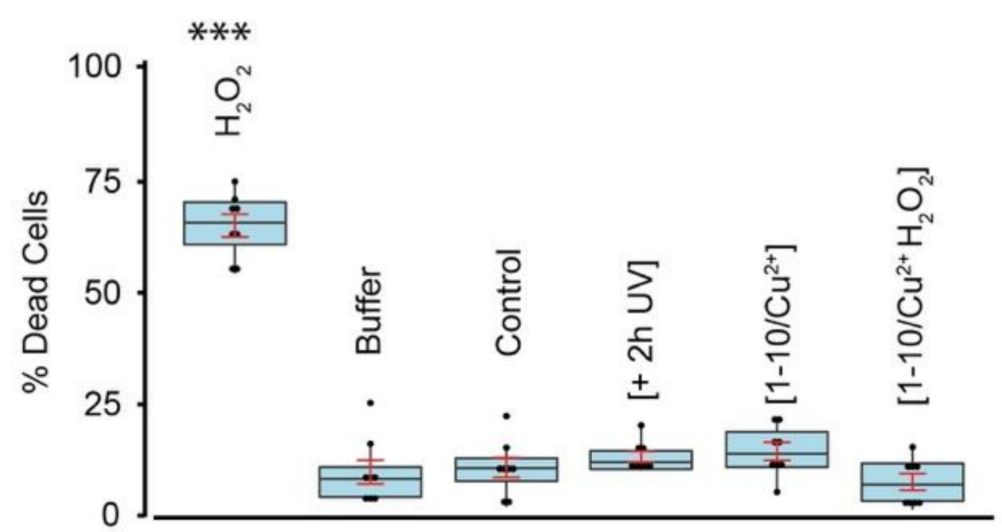

Figure 6. Cell death assay. Differentiated SHSY5Y cells were incubated for three days in the presence of phosphate buffer, or $10 \mu \mathrm{M} 2 \mathrm{~h}$ UV-exposed dGAE, $10 \mu \mathrm{M}$ three days $/ 37^{\circ} \mathrm{C}$-incubated dGAE control, [1-10/ $\left.\mathrm{Cu}^{2+}\right]$ sample and [1-10/ $\left.\mathrm{Cu}^{2+} \mathrm{H}_{2} \mathrm{O}_{2}\right]$ sample. $1 \mathrm{~h}$ incubation of cells with $2 \mathrm{mM}$ $\mathrm{H}_{2} \mathrm{O}_{2}$ was used as a positive control. At the end of the incubation period, cells were incubated with ReadyProbes reagent for $15 \mathrm{~min}$, imaged at $37^{\circ} \mathrm{C}$ and $5 \% \mathrm{CO}_{2}$ using Operetta CLS high-content analysis system, and at least 5000 dead and live cells were used for analysis. Only cells treated with $2 \mathrm{mM} \mathrm{H}_{2} \mathrm{O}_{2}$ showed a significant \% of dead cells compared to control. ${ }^{* * *}$ indicates $p$ value $<0.001$.

\section{Discussion}

Oxidative stress has been proposed to play a key role in $\mathrm{AD}[48,49]$ and it has been suggested that it may be among the earliest sources of damage in human AD [17]. The levels of nitrotyrosine and DiY, two products of oxidative modification, have been shown to be significantly increased in the AD brain [18]. The cross-linking of proteins by DiY enhances their stability [19], as demonstrated by the occurrence in tough proteins such as resilin. Indeed, DiY cross-links occur naturally in several elastic and structural proteins including elastin, fibroin, keratin, cuticlin, and collagen [50-53]. In these proteins, DiY cross-links can contribute to increased mechanical strength and protein insolubility [54]. DiY crosslinking has been shown to form and influence the aggregation of both $A \beta$ and $\alpha$-synuclein in vitro under oxidative environments [20-22,41]. We have previously demonstrated that DiY cross-linking stabilises $A \beta$ and $\alpha$-synuclein fibrils in vitro and revealed the presence of DiY-cross-linked A $\beta$ fibrils in A $\beta$ plaques and DiY cross-linked $\alpha$-synuclein in Lewy bodies $[22,23]$. These findings suggest that oxidative stress influences $A \beta$ and $\alpha$-synuclein assembly and stability via DiY cross-linking but the role of DiY on tau assembly remains unclear. Here, we have explored this question and revealed that the region of tau that forms the core of PHFs, dGAE, is able to form DiY via Y310 in vitro. We show that DiY formation facilitates the formation of non-toxic, soluble tau oligomers and inhibits the elongation of the oligomers to fibrils. DiY was induced rapidly in dGAE either via $\mathrm{Cu}^{2+}$ catalysed oxidation or UV photo-oxidation. Interestingly, DiY cross-linking facilitated the formation of T22-positive tau oligomers in a DiY-dependent manner. Collectively, $\mathrm{CD}$, ThS fluorescence and TEM revealed that the DiY cross-linked dGAE oligomers are random-coil rich, ThS-negative, amorphous aggregates and are unable to elongate to form fibrils. Previous studies revealed that oxidative stress induced by peroxynitrate results in the oligomerisation of full-length human tau stabilised via DiY cross-linking [12].

Multiple strands of evidence support the idea that metal ions may play a role in AD pathogenesis. The aberrant distribution of copper, iron, and zinc has been shown in the 
AD brain [55]. For example, $\sim 400 \mu \mathrm{M}$ copper has been estimated around $\mathrm{A} \beta$ plaques [55]. There is substantial evidence that copper can influence $A \beta$ and tau aggregation $[42,43]$ and efficiently catalyse DiY cross-linking on $\mathrm{A} \beta$ and $\alpha$-synuclein $[22,23]$. Copper can bind tau via its microtubule-binding repeat region [42,56], which is contained in the dGAE fragment used in this study [30]. Here, we showed that, at a supra-equimolar ratio, $\mathrm{Cu}^{2+}$ facilitates DiY cross-linking and tau oligomerisation, prolongs the oligomer half-life and inhibits the further assembly of the oligomers into fibrils. At a sub-equimolar ratio, $\mathrm{Cu}^{2+}$ appears not to influence dGAE assembly. Indeed, multiple researchers have studied the influence of copper on tau aggregation, and this is still not fully understood. The impact of copper on tau appears to depend on the tau isoform, $\mathrm{pH}$, temperature and other factors [42,57-59]. It would be of interest to characterise the concentration-dependent role of $\mathrm{Cu}^{2+}$ on tau more fully in both in vitro and in vivo environments.

DiY cross-linking has been demonstrated in preformed tau fibrils, leading to the suggestion that cross-linking may be essential for tau filament assembly [60]. In contrast, we have shown that that DiY cross-linking before the onset of assembly promotes tau oligomerisation but inhibits further elongation. By TEM, the DiY cross-linked dGAE assemblies showed large clumped aggregates that appear to be composed of amorphous oligomers and this is supported by the observation of random coil conformation retained in these samples by CD. This may suggest that the cross-linking traps the oligomers in a conformation that does not favour further elongation to fibrils although cross-linking in tau filaments may stabilise the assemblies [60]. However, the nature of tau fibrils and accessibility of the tyrosine residues will be critical for their ability to form DiY cross-links. In the core of PHFs and straight filaments, Y310 is buried in one of the eight $\beta$-sheets that run along the length of the protofilament, adopting a C-shaped architecture [32]. If the tyrosine residues are not exposed, DiY formation may be impeded. Nonetheless, given that there are several tyrosine residues located at residues 18, 29, 197, 310, and 394, DiY could still form with the other tyrosine residues, which would lead to enhanced stability and increased insolubility of PHFs [60]. PHFs derived from the AD brain demonstrate striking insolubility and resistance to proteolytic cleavage. Early-stage PHF-tau has decreased SDS solubility [61,62], while late-stage PHF tau exhibits SDS and sarcosyl insolubility [62-64]. Thus, it has been proposed that DiY cross-linking is important for the stabilisation of the early-stage PHF-tau, which confers stability to the PHFs and their conversion into late-stage PHFs [60]. Overall, our results suggest that DiY can influence the assembly process of tau, but that oxidation at the early stages of assembly result in formation of oligomers that do not progress to form PHFs.

Multiple studies have reported the toxic properties of tau oligomers [35-38,65]. Here, tau oligomers formed as a result of the DiY cross-linking are ThS-negative and random-coil rich, unlike typically studied tau oligomers which are thought to be insoluble and $\beta$-sheet rich $[35,66]$. None of the dGAE oligomers (formed with and without oxidation) resulted in cell death of differentiated neuroblastoma cells during the incubation period studied. This suggests that these oligomers are either not toxic under these conditions, or that they cause more subtle forms of neuronal dysfunction not measured here. For instance, it was shown that low-n tau ${ }^{\mathrm{RD}} \Delta \mathrm{K}$ oligomers selectively impaired spine morphology and density, accompanied by increased reactive oxygen species and intracellular calcium, but without affecting cell viability [67]. However these oligomers were ThS-positive and have partial $\beta$-sheet conformation [67], unlike the DiY cross-linked oligomers reported here which are ThS-negative and random-coil rich. This may indicate that the DiY cross-linking facilitates the formation of non-toxic, off-pathway tau oligomers. Previous work has shown that the rescue of tau toxicity in Drosophila results in the formation of non-toxic tau oligomers lacking $\beta$-sheet [44]. Similarly, it has also been demonstrated that the inhibition of tau aggregation using phthalocyanine tetrasulfonate (PcTS) results in the formation of $\beta$-sheet negative, soluble tau oligomers [68]. In the latter study, it was shown that PcTS interacts with tyrosine residues on tau, including Y310 to induce its assembly into oligomers. This is interesting given that the DiY cross-linking observed in our work occurs via Y310 since it is 
the only tyrosine in the dGAE fragment. This suggests that the accessibility of this residue may be involved in the generation of this $\beta$-sheet negative oligomeric tau species.

Another factor that may influence our findings, including the lack of cell death in the presence of the DiY cross-linked dGAE oligomers, could be the presence of additional oxidative modifications. For example, the nitration of tyrosine residues on tau has been shown to occur alongside DiY cross-linking leading to tau oligomerisation and stabilisation [24,60]. In vitro treatment of tau with peroxynitrite has been shown to induce other oxidative modifications, including lysine formylation [69]. Moreover, tau could be oxidised on cysteine residues [70,71]. Chronic oxidative stress can also lead to tau phosphorylation [72] which may play an important role in the toxic effects of tau. Thus, the oxidative condition used in our study could have resulted in multiple oxidative modifications, which may collectively impact on dGAE oligomerisation and toxicity. Future studies will fully characterise the specific oxidative modifications on dGAE to ascertain their specific contribution to dGAE oligomerisation and toxicity as well as the effect of DiY on preformed filaments. Overall, our work provides evidence regarding the diversity of tau oligomers and that the structural conformation of the oligomers may be key to their toxicity. Controlled and specific cross-linking of tau may be an avenue for further research.

In conclusion, our findings suggest that DiY formation facilitates the oligomerisation of dGAE but inhibits, or significantly delays, its elongation into fibrils. We have shown that DiY cross-linked soluble dGAE oligomers do not cause loss in cell viability. This finding has implications for understanding the toxic species of tau and therapeutic approaches aimed at inhibiting tau aggregation.

Author Contributions: M.B.M. planned and carried out the work; Y.K.A.-H., G.B. and J.E.R. contributed experimental work; M.B.M. and L.C.S. wrote the paper; Y.K.A.-H. edited the paper and provided training. C.R.H. and C.M.W. reviewed the paper; L.C.S. managed the project. All authors have read and agreed to the published version of the manuscript.

Funding: This work was supported by funding from Alzheimer's Society [345 (AS-PG-16b-010)] awarded to L.C.S. and funding M.B.M. Y.K.A.-H. is supported by WisTa Laboratories Ltd. (PAR1596). The work was supported by ARUK South Coast Network. G.B. was supported by European Molecular Biology Organisation (EMBO) Short-Term Fellowship award (EMBO-STF 7674). LCS is supported by BBSRC [BB/S003657/1].

Institutional Review Board Statement: Not applicable.

Informed Consent Statement: Not applicable.

Data Availability Statement: Data is contained within the article; raw data is available from the corresponding author on reasonable request.

Acknowledgments: TEM work was performed at the University of Sussex's Electron microscopy imaging centre (EMC), funded by the School of Life Sciences, the Wellcome Trust (095605/Z/11/A, 208348/Z/17/Z) and the RM Phillips Trust. The authors thank Pascale Schellenberger for valuable support.

Conflicts of Interest: C.R.H. and C.M.W. hold Offices within TauRx Therapeutics Ltd. and are named inventors on patents in the field of tau protein in neurodegenerative disorders. The funding sponsors had no role in the design of the study; in the collection, analyses, or interpretation of data; in the writing of the manuscript, and in the decision to publish the results.

\section{References}

1. Grundke-Iqbal, I.; Iqbal, K.; Tung, Y.C.; Quinlan, M.; Wisniewski, H.M.; Binder, L.I. Abnormal phosphorylation of the microtubuleassociated protein tau (tau) in Alzheimer cytoskeletal pathology. Proc. Natl. Acad. Sci. USA 1986, 83, 4913-4917. [CrossRef]

2. Wischik, C.M.; Novak, M.; Thogersen, H.C.; Edwards, P.C.; Runswick, M.J.; Jakes, R.; Walker, J.E.; Milstein, C.; Roth, M.; Klug, A. Isolation of a fragment of tau derived from the core of the paired helical filament of Alzheimer disease. Proc. Natl. Acad. Sci. USA 1988, 85, 4506-4510. [CrossRef]

3. Arriagada, P.V.; Growdon, J.H.; Hedley-Whyte, E.T.; Hyman, B.T. Neurofibrillary tangles but not senile plaques parallel duration and severity of Alzheimer's disease. Neurology 1992, 42, 631-639. [CrossRef] 
4. Braak, H.; Braak, E. Neuropathological stageing of Alzheimer-related changes. Acta Neuropathol. 1991, 82, 239-259. [CrossRef] [PubMed]

5. Cowan, C.M.; Mudher, A. Are tau aggregates toxic or protective in tauopathies? Front. Neurol. 2013, 4, 114. [CrossRef]

6. Berger, Z.; Roder, H.; Hanna, A.; Carlson, A.; Rangachari, V.; Yue, M.; Wszolek, Z.; Ashe, K.; Knight, J.; Dickson, D.; et al. Accumulation of pathological tau species and memory loss in a conditional model of tauopathy. J. Neurosci. 2007, 27, 3650-3662. [CrossRef] [PubMed]

7. Lasagna-Reeves, C.A.; Castillo-Carranza, D.L.; Sengupta, U.; Clos, A.L.; Jackson, G.R.; Kayed, R. Tau oligomers impair memory and induce synaptic and mitochondrial dysfunction in wild-type mice. Mol. Neurodegener. 2011, 6, 39. [CrossRef]

8. Castillo-Carranza, D.L.; Gerson, J.E.; Sengupta, U.; Guerrero-Muñoz, M.J.; Lasagna-Reeves, C.A.; Kayed, R. Specific targeting of tau oligomers in Htau mice prevents cognitive impairment and tau toxicity following injection with brain-derived tau oligomeric seeds. J. Alzheimer's Dis. 2014, 40, S97-S111. [CrossRef]

9. Clavaguera, F.; Akatsu, H.; Fraser, G.; Crowther, R.A.; Frank, S.; Hench, J.; Probst, A.; Winkler, D.T.; Reichwald, J.; Staufenbiel, M.; et al. Brain homogenates from human tauopathies induce tau inclusions in mouse brain. Proc. Natl. Acad. Sci. USA 2013, 110, 9535-9540. [CrossRef] [PubMed]

10. Maeda, S.; Sahara, N.; Saito, Y.; Murayama, S.; Ikai, A.; Takashima, A. Increased levels of granular tau oligomers: An early sign of brain aging and Alzheimer's disease. Neurosci. Res. 2006, 54, 197-201. [CrossRef] [PubMed]

11. Martin, L.; Latypova, X.; Terro, F. Post-translational modifications of tau protein: Implications for Alzheimer's disease. Neurochem. Int. 2011, 58, 458-471. [CrossRef]

12. Reynolds, M.R.; Berry, R.W.; Binder, L.I. Site-specific nitration and oxidative dityrosine bridging of the tau protein by peroxynitrite: Implications for Alzheimer's disease. Biochemistry 2005, 44, 1690-1700. [CrossRef] [PubMed]

13. Mondragón-Rodríguez, S.; Perry, G.; Zhu, X.; Moreira, P.I.; Acevedo-Aquino, M.C.; Williams, S. Phosphorylation of tau protein as the link between oxidative stress, mitochondrial dysfunction, and connectivity failure: Implications for Alzheimer's disease. Oxid. Med. Cell. Longev. 2013, 2013, 1-6. [CrossRef]

14. Maina, M.B.; Bailey, L.J.; Wagih, S.; Biasetti, L.; Pollack, S.J.; Quinn, J.P.; Thorpe, J.R.; Doherty, A.J.; Serpell, L.C. The involvement of tau in nucleolar transcription and the stress response. Acta Neuropathol. Commun. 2018, 6, 1-13. [CrossRef] [PubMed]

15. Cohen, T.J.; Guo, J.L.; Hurtado, D.E.; Kwong, L.K.; Mills, I.P.; Trojanowski, J.Q.; Lee, V.M.Y. The acetylation of tau inhibits its function and promotes pathological tau aggregation. Nat. Commun. 2011, 2, 252. [CrossRef] [PubMed]

16. Carlomagno, Y.; Chung, D.-E.C.; Yue, M.; Castanedes-Casey, M.; Madden, B.J.; Dunmore, J.; Tong, J.; DeTure, M.; Dickson, D.W.; Petrucelli, L.; et al. An acetylation-phosphorylation switch that regulates tau aggregation propensity and function. J. Biol. Chem. 2017, 292, 15277-15286. [CrossRef] [PubMed]

17. Nunomura, A.; Perry, G.; Aliev, G.; Hirai, K.; Takeda, A.; Balraj, E.K.; Jones, P.K.; Ghanbari, H.; Wataya, T.; Shimohama, S.; et al. Oxidative damage is the earliest event in Alzheimer disease. J. Neuropathol. Exp. Neurol. 2001, 60, 759-767. [CrossRef]

18. Hensley, K.; Maidt, M.L.; Yu, Z.; Sang, H.; Markesbery, W.R.; Floyd, R.A. Electrochemical analysis of protein nitrotyrosine and dityrosine in the Alzheimer brain indicates region-specific accumulation. J. Neurosci. 1998, 18, 8126-8132. [CrossRef]

19. Gross, A.J.; Sizer, I.W. The oxidation of tyramine, tyrosine, and related compounds by peroxidase. J. Biol. Chem. 1959, 234, 1611-1614. [CrossRef]

20. Galeazzi, L.; Ronchi, P.; Franceschi, C.; Giunta, S. In vitro peroxidase oxidation induces stable dimers of $\beta$-amyloid (1-42) through dityrosine bridge formation. Amyloid 1999, 6, 7-13. [CrossRef]

21. Souza, J.M.; Giasson, B.I.; Chen, Q.; Lee, V.M.; Ischiropoulos, H. Dityrosine cross-linking promotes formation of stable alpha -synuclein polymers. Implication of nitrative and oxidative stress in the pathogenesis of neurodegenerative synucleinopathies. J. Biol. Chem. 2000, 275, 18344-18349. [CrossRef]

22. Al-Hilaly, Y.K.; Williams, T.L.; Stewart-Parker, M.; Ford, L.; Skaria, E.; Cole, M.; Bucher, W.G.; Morris, K.L.; Sada, A.A.; Thorpe, J.R.; et al. A central role for dityrosine crosslinking of Amyloid- $\beta$ in Alzheimer's disease. Acta Neuropathol. Commun. 2013, 1, 83. [CrossRef]

23. Al-Hilaly, Y.K.; Biasetti, L.; Blakeman, B.J.F.; Pollack, S.J.; Zibaee, S.; Abdul-Sada, A.; Thorpe, J.R.; Xue, W.-F.; Serpell, L.C. The involvement of dityrosine crosslinking in $\alpha$-synuclein assembly and deposition in Lewy bodies in Parkinson's disease. Sci. Rep. 2016, 6, 39171. [CrossRef] [PubMed]

24. Reynolds, M.R.; Berry, R.W.; Binder, L.I. Site-specific nitration differentially influences tau assembly in vitro. Biochemistry 2005, 44, 13997-14009. [CrossRef] [PubMed]

25. Goedert, M.; Jakes, R.; Spillantini, M.G.; Hasegawa, M.; Smith, M.J.; Crowther, R.A. Assembly of microtubule-associated protein tau into Alzheimer-like filaments induced by sulphated glycosaminoglycans. Nat. Cell Biol. 1996, 383, 550-553. [CrossRef] [PubMed]

26. Pérez, M.; Valpuesta, J.M.; Medina, M.; de Garcini, E.M.; Avila, J. Polymerization of tau into filaments in the presence of heparin: The minimal sequence required for tau-tau interaction. J. Neurochem. 1996, 67, 1183-1190. [CrossRef] [PubMed]

27. Kampers, T.; Friedhoff, P.; Biernat, J.; Mandelkow, E.-M. RNA stimulates aggregation of microtubule-associated protein tau into Alzheimer-like paired helical filaments. FEBS Lett. 1996, 399, 344-349. [CrossRef]

28. Wilson, D.M.; Binder, L.I. Free fatty acids stimulate the polymerization of tau and amyloid beta peptides. In vitro evidence for a common effector of pathogenesis in Alzheimer's disease. Am. J. Pathol. 1997, 150, 2181-2195. [PubMed] 
29. Friedhoff, P.; Schneider, A.; Mandelkow, E.M.; Mandelkow, E. Rapid assembly of Alzheimer-like paired helical filaments from microtubule-associated protein tau monitored by fluorescence in solution. Biochemistry 1998, 37, 10223-10230. [CrossRef]

30. Al-Hilaly, Y.K.; Pollack, S.J.; Vadukul, D.M.; Citossi, F.; Rickard, J.E.; Simpson, M.; Storey, J.M.D.; Harrington, C.R.; Wischik, C.M.; Serpell, L.C. Alzheimer's disease-like paired helical filament assembly from truncated tau protein is independent of disulfide crosslinking. J. Mol. Biol. 2017, 429, 3650-3665. [CrossRef]

31. Al-Hilaly, Y.K.; Foster, B.E.; Biasetti, L.; Lutter, L.; Pollack, S.J.; Rickard, J.E.; Storey, J.M.D.; Harrington, C.R.; Xue, W.; Wischik, C.M.; et al. Tau (297-391) forms filaments that structurally mimic the core of paired helical filaments in Alzheimer's disease brain. FEBS Lett. 2020, 594, 944-950. [CrossRef] [PubMed]

32. Fitzpatrick, A.W.P.; Falcon, B.; Michel, G.; Murzin, A.G.; Murshudov, G.; Garringer, H.J.; Crowther, R.A.; Ghetti, B.; Goedert, M.; Scheres, S.H.W. Cryo-EM structures of tau filaments from Alzheimer's disease. Nat. Cell Biol. 2017, 547, 185-190. [CrossRef]

33. Von Bergen, M.; Friedhoff, P.; Biernat, J.; Heberle, J.; Mandelkow, E.-M. Assembly of tau protein into Alzheimer paired helical filaments depends on a local sequence motif (306VQIVYK311) forming beta structure. Proc. Natl. Acad. Sci. USA 2000, 97, 5129-5134. [CrossRef]

34. Ganguly, P.; Do, T.D.; Larini, L.; Lapointe, N.E.; Sercel, A.J.; Shade, M.F.; Feinstein, S.C.; Bowers, M.T.; Shea, J.-E. Tau assembly: The dominant role of PHF6 (VQIVYK) in microtubule binding region repeat R3. J. Phys. Chem. B 2015, 119, 4582-4593. [CrossRef] [PubMed]

35. Lasagna-Reeves, C.A.; Castillo-Carranza, D.L.; Guerrero-Muñoz, M.J.; Jackson, G.R.; Kayed, R. Preparation and characterization of neurotoxic tau oligomers. Biochemistry 2010, 49, 10039-10041. [CrossRef]

36. Flach, K.; Hilbrich, I.; Schiffmann, A.; Gärtner, U.; Krüger, M.; Leonhardt, M.; Waschipky, H.; Wick, L.; Arendt, T.; Holzer, M. Tau oligomers impair artificial membrane integrity and cellular viability. J. Biol. Chem. 2012, 287, 43223-43233. [CrossRef] [PubMed]

37. Chen, L.; Wei, Y.; Wang, X.; He, R. D-Ribosylated tau forms globular aggregates with high cytotoxicity. Cell. Mol. Life Sci. 2009, 66, 2559-2571. [CrossRef]

38. Tian, H.; Davidowitz, E.; Lopez, P.; Emadi, S.; Moe, J.; Sierks, M. Trimeric tau is toxic to human neuronal cells at low nanomolar concentrations. Int. J. Cell Biol. 2013, 2013, 1-9. [CrossRef]

39. Lasagna-Reeves, C.A.; Castillo-Carranza, D.L.; Sengupta, U.; Sarmiento, J.; Troncoso, J.; Jackson, G.R.; Kayed, R. Identification of oligomers at early stages of tau aggregation in Alzheimer's disease. FASEB J. 2012, 26, 1946-1959. [CrossRef] [PubMed]

40. Yoburn, J.C.; Tian, W.; Brower, J.O.; Nowick, J.S.; Glabe, C.G.; Van Vranken, D.L. Dityrosine cross-linked Abeta peptides: Fibrillar beta-structure in Abeta(1-40) is conducive to formation of dityrosine cross-links but a dityrosine cross-link in Abeta(8-14) does not induce beta-structure. Chem. Res. Toxicol. 2003, 16, 531-535. [CrossRef]

41. Maina, M.B.; Burra, G.; Al-Hilaly, Y.K.; Mengham, K.; Fennell, K.; Serpell, L.C. Metal- and UV- catalyzed oxidation results in trapped amyloid- $\beta$ intermediates revealing that self-assembly is required for A $\beta$-induced cytotoxicity. iScience 2020, $23,101537$. [CrossRef] [PubMed]

42. Soragni, A.; Zambelli, B.; Mukrasch, M.D.; Biernat, J.; Jeganathan, S.; Griesinger, C.; Ciurli, S.; Mandelkow, E.; Zweckstetter, M. Structural characterization of binding of $\mathrm{Cu}(\mathrm{II})$ to tau protein. Biochemistry 2008, 47, 10841-10851. [CrossRef] [PubMed]

43. Kim, A.C.; Lim, S.; Kim, Y.K. Metal ion effects on Abeta and tau Aggregation. Int. J. Mol. Sci. 2018, 19, 128. [CrossRef]

44. Cowan, C.M.; Quraishe, S.; Hands, S.; Sealey, M.; Mahajan, S.; Allan, D.W.; Mudher, A. Rescue from tau-induced neuronal dysfunction produces insoluble tau oligomers. Sci. Rep. 2015, 5, 17191. [CrossRef] [PubMed]

45. Sonawane, S.K.; Uversky, V.N.; Chinnathambi, S. Baicalein inhibits heparin-induced Tau aggregation by initializing non-toxic Tau oligomer formation. Cell Commun. Signal. 2021, 19, 1-16. [CrossRef] [PubMed]

46. Jämsä, A.; Hasslund, K.; Cowburn, R.F.; Bäckström, A.; Vasänge, M. The retinoic acid and brain-derived neurotrophic factor differentiated SH-SY5Y cell line as a model for Alzheimer's disease-like tau phosphorylation. Biochem. Biophys. Res. Commun. 2004, 319, 993-1000. [CrossRef] [PubMed]

47. Pollack, S.J.; Trigg, J.; Khanom, T.; Biasetti, L.; Marshall, K.E.; Al-Hilaly, Y.K.; Rickard, J.E.; Harrington, C.R.; Wischik, C.M.; Serpell, L.C. Paired helical filament-forming region of tau (297-391) influences endogenous tau protein and accumulates in acidic compartments in human neuronal cells. J. Mol. Biol. 2020, 432, 4891-4907. [CrossRef]

48. Butterfield, D.A.; Halliwell, B. Oxidative stress, dysfunctional glucose metabolism and Alzheimer disease. Nat. Rev. Neurosci. 2019, 20, 148-160. [CrossRef]

49. Butterfield, D.A.; Swomley, A.M.; Sultana, R. Amyloid beta-peptide (1-42)-induced oxidative stress in Alzheimer disease: Importance in disease pathogenesis and progression. Antioxid. Redox Signal. 2013, 19, 823-835. [CrossRef]

50. Labella, F.; Keeley, F.; Vivian, S.; Thornhill, D. Evidence for dityrosine in elastin. Biochem. Biophys. Res. Commun. 1967, 26, 748-753. [CrossRef]

51. Raven, D.J.; Earland, C.; Little, M. Occurrence of dityrosine in Tussah silk fibroin and keratin. Biochim. Biophys. Acta (BBA) Protein Struct. 1971, 251, 96-99. [CrossRef]

52. Fujimoto, D. Occurrence of dityrosine in cuticlin, a structural protein from Ascaris cuticle. Comp. Biochem. Physiol. Part B Comp. Biochem. 1975, 51, 205-207. [CrossRef]

53. Waykole, P.; Heidemann, E. Dityrosine in Collagen. Connect. Tissue Res. 1976, 4, 219-222. [CrossRef] [PubMed]

54. Skaff, O.; Jolliffe, K.A.; Hutton, C.A. Synthesis of the side chain cross-linked tyrosine oligomers dityrosine, trityrosine, and pulcherosine. J. Org. Chem. 2005, 70, 7353-7363. [CrossRef] [PubMed] 
55. Lovell, M.A.; Robertson, J.D.; Teesdale, W.J.; Campbell, J.L.; Markesbery, W.R. Copper, iron and zinc in Alzheimer's disease senile plaques. J. Neurol. Sci. 1998, 158, 47-52. [CrossRef]

56. Shin, B.-K.; Saxena, S. Insight into potential Cu(II)-binding motifs in the four pseudorepeats of tau protein. J. Phys. Chem. B 2011, 115, 15067-15078. [CrossRef]

57. Ma, Q.; Li, Y.; Du, J.; Liu, H.; Kanazawa, K.; Nemoto, T.; Nakanishi, H.; Zhao, Y. Copper binding properties of a tau peptide associated with Alzheimer's disease studied by CD, NMR, and MALDI-TOF MS. Peptides 2006, 27, 841-849. [CrossRef] [PubMed]

58. Zhou, L.-X.; Du, J.-T.; Zeng, Z.-Y.; Wu, W.-H.; Zhao, Y.-F.; Kanazawa, K.; Ishizuka, Y.; Nemoto, T.; Nakanishi, H.; Li, Y.-M. Copper (II) modulates in vitro aggregation of a tau peptide. Peptides 2007, 28, 2229-2234. [CrossRef]

59. Di Natale, G.; Bellia, F.; Sciacca, M.F.; Campagna, T.; Pappalardo, G. Tau-peptide fragments and their copper(II) complexes: Effects on amyloid- $\beta$ aggregation. Inorg. Chim. Acta 2018, 472, 82-92. [CrossRef]

60. Reynolds, M.R.; Lukas, T.J.; Berry, R.W.; Binder, L.I. Peroxynitrite-Mediated $\tau$ modifications stabilize preformed filaments and destabilize microtubules through distinct mechanisms. Biochemistry 2006, 45, 4314-4326. [CrossRef] [PubMed]

61. Lee, V.M.; Balin, B.J.; Otvos, L.; Trojanowski, J.Q. A68: A major subunit of paired helical filaments and derivatized forms of normal Tau. Science 1991, 251, 675-678. [CrossRef] [PubMed]

62. Greenberg, S.G.; Davies, P. A preparation of Alzheimer paired helical filaments that displays distinct tau proteins by polyacrylamide gel electrophoresis. Proc. Natl. Acad. Sci. USA 1990, 87, 5827-5831. [CrossRef] [PubMed]

63. Kondo, J.; Honda, T.; Mori, H.; Hamada, Y.; Miura, R.; Ogawara, M.; Ihara, Y. The carboxyl third of tau is tightly bound to paired helical filaments. Neuron 1988, 1, 827-834. [CrossRef]

64. Miao, J.; Shi, R.; Li, L.; Chen, F.; Zhou, Y.; Tung, Y.C.; Hu, W.; Gong, C.-X.; Iqbal, K.; Liu, F. Pathological tau from Alzheimer's brain induces site-specific hyperphosphorylation and SDS- and reducing agent-resistant aggregation of tau in vivo. Front. Aging Neurosci. 2019, 11, 34. [CrossRef]

65. Usenovic, M.; Niroomand, S.; Drolet, R.E.; Yao, L.; Gaspar, R.C.; Hatcher, N.G.; Schachter, J.; Renger, J.J.; Parmentier-Batteur, S. Internalized tau oligomers cause neurodegeneration by inducing accumulation of pathogenic tau in human neurons derived from induced pluripotent stem cells. J. Neurosci. 2015, 35, 14234-14250. [CrossRef]

66. Li, D.-W.; Mohanty, S.; Irbäck, A.; Huo, S. Formation and growth of oligomers: A Monte Carlo study of an amyloid tau fragment. PLoS Comput. Biol. 2008, 4, e1000238. [CrossRef]

67. Kaniyappan, S.; Chandupatla, R.R.; Mandelkow, E.M.; Mandelkow, E. Extracellular low-n oligomers of tau cause selective synaptotoxicity without affecting cell viability. Alzheimers Dement. 2017, 13, 1270-1291. [CrossRef]

68. Akoury, E.; Gajda, M.; Pickhardt, M.; Biernat, J.; Soraya, P.; Griesinger, C.; Mandelkow, E.; Zweckstetter, M. Inhibition of tau filament formation by conformational modulation. J. Am. Chem. Soc. 2013, 135, 2853-2862. [CrossRef]

69. Vana, L.; Kanaan, N.M.; Hakala, K.; Weintraub, S.T.; Binder, L.I. Peroxynitrite-induced nitrative and oxidative modifications alter tau filament formation. Biochemistry 2011, 50, 1203-1212. [CrossRef]

70. Schweers, O.; Mandelkow, E.M.; Biernat, J. Oxidation of cysteine-322 in the repeat domain of microtubule-associated protein tau controls the in vitro assembly of paired helical filaments. Proc. Natl. Acad. Sci. USA 1995, 92, 8463-8467. [CrossRef]

71. Landino, L.M.; Skreslet, T.E.; Alston, J.A. Cysteine oxidation of tau and microtubule-associated protein-2 by peroxynitrite: Modulation of microtubule assembly kinetics by the thioredoxin reductase system. J. Biol. Chem. 2004, $279,35101-35105$. [CrossRef] [PubMed]

72. Su, B.; Wang, X.; Lee, H.-G.; Tabaton, M.; Perry, G.; Smith, M.A.; Zhu, X. Chronic oxidative stress causes increased tau phosphorylation in M17 neuroblastoma cells. Neurosci. Lett. 2010, 468, 267-271. [CrossRef] [PubMed] 